\title{
Technology Evaluation for Waterborne Mercury Removal at the Y-12 National Security Complex
}

\section{December 2010}

\author{
Prepared by \\ Feng He \\ Liyuan Liang \\ Carrie Miller
}

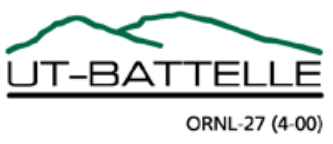




\title{
DOCUMENT AVAILABILITY
}

Reports produced after January 1, 1996, are generally available free via the U.S. Department of Energy (DOE) Information Bridge.

Web site http://www.osti.gov/bridge

Reports produced before January 1, 1996, may be purchased by members of the public from the following source.

National Technical Information Service

5285 Port Royal Road

Springfield, VA 22161

Telephone 703-605-6000 (1-800-553-6847)

TDD 703-487-4639

Fax 703-605-6900

E-mail info@ntis.gov

Web site http://www.ntis.gov/support/ordernowabout.htm

Reports are available to DOE employees, DOE contractors, Energy Technology Data Exchange (ETDE) representatives, and International Nuclear Information System (INIS) representatives from the following source.

Office of Scientific and Technical Information

P.O. Box 62

Oak Ridge, TN 37831

Telephone 865-576-8401

Fax 865-576-5728

E-mail reports@osti.gov

Web site http://www.osti.gov/contact.html

\begin{abstract}
This report was prepared as an account of work sponsored by an agency of the United States Government. Neither the United States Government nor any agency thereof, nor any of their employees, makes any warranty, express or implied, or assumes any legal liability or responsibility for the accuracy, completeness, or usefulness of any information, apparatus, product, or process disclosed, or represents that its use would not infringe privately owned rights. Reference herein to any specific commercial product, process, or service by trade name, trademark, manufacturer, or otherwise, does not necessarily constitute or imply its endorsement, recommendation, or favoring by the United States Government or any agency thereof. The views and opinions of authors expressed herein do not necessarily state or reflect those of the United States Government or any agency thereof.
\end{abstract}




\title{
TECHNOLOGY EVALUATION FOR WATERBORNE MERCURY REMOVAL AT THE Y-12 NATIONAL SECURITY COMPLEX
}

\author{
Feng He \\ Liyuan Liang \\ Carrie Miller
}

Date Published: December 2010

\author{
Prepared by \\ OAK RIDGE NATIONAL LABORATORY \\ Oak Ridge, Tennessee 37831-6283 \\ managed by \\ UT-BATTELLE, LLC \\ for the \\ U.S. DEPARTMENT OF ENERGY \\ under contract DE-AC05-00OR22725
}




\section{CONTENTS}

Page

LIST OF FIGURES

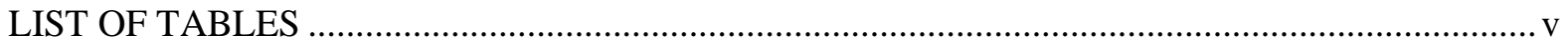

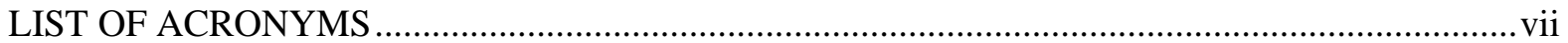

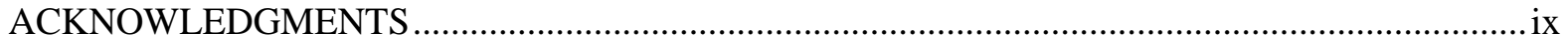

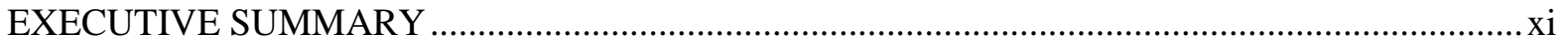

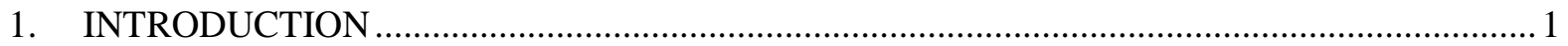

2. OVERVIEW OF WATERBORNE MERCURY TREATMENT TECHNOLOGIES ................... 3

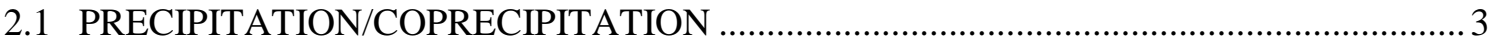

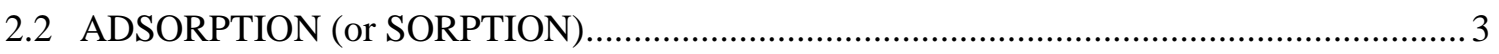

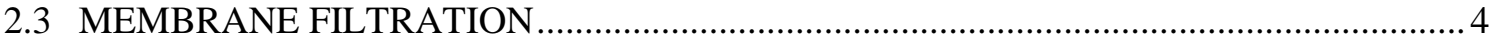

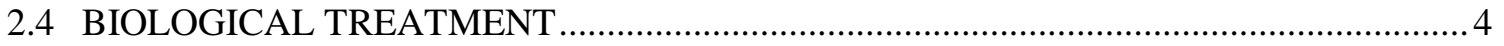

2.5 CHEMICAL REDUCTION COUPLED WITH AIR STRIPPING ....................................... 5

3. WATERBORNE MERCURY REMOVAL BY CHEMICAL REDUCTION............................ 6

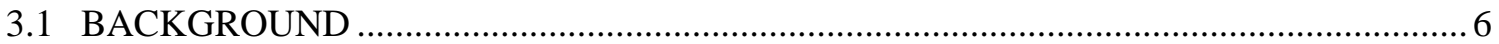

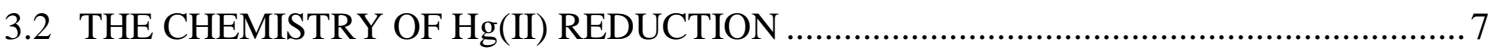

3.3 STANNOUS CHLORIDE REDUCTION FIELD TESTS …................................................ 8

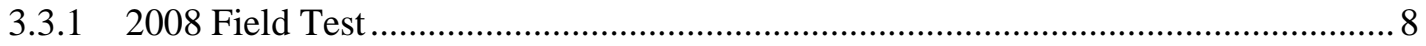

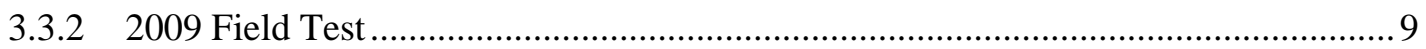

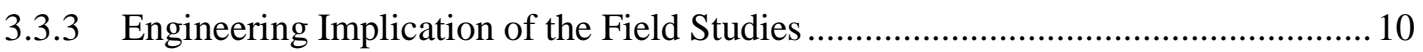

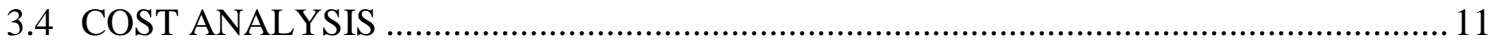

3.5 UNCERTAINTIES ASSOCIATED WITH FULL-SCALE IMPLEMENTATION ............11

4. WATERBORNE MERCURY REMOVAL BY SORPTION ….............................................. 12

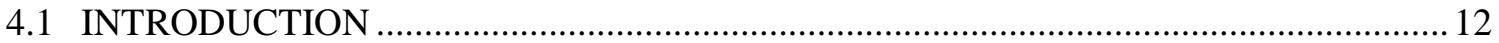

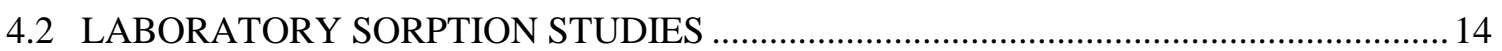

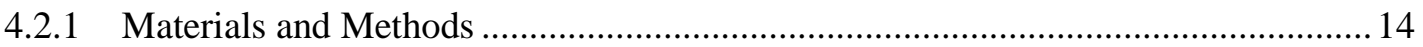

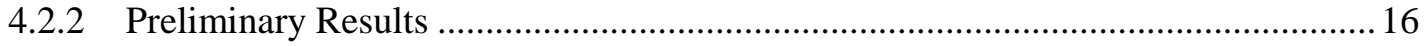

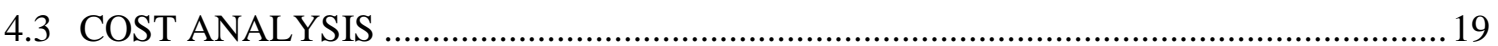

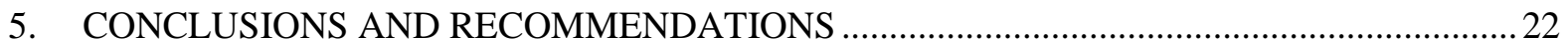

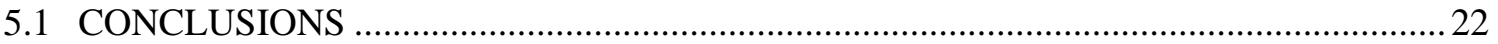

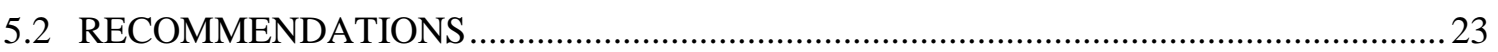

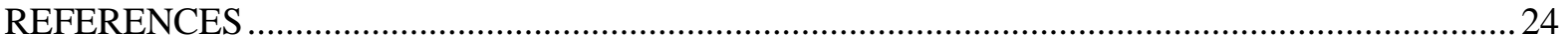





\section{LIST OF FIGURES}

Figure $\quad$ Page

$1 \quad$ Oak Ridge Reservation showing the major monitoring locations, including Station 17

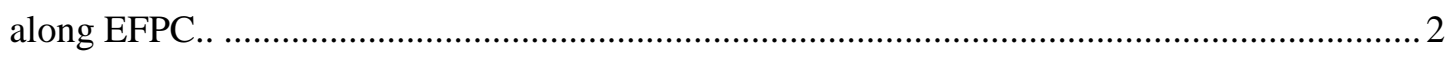

2 Schematic of the $\mathrm{SnCl}_{2}$ chemical reduction field test in the $\mathrm{Y}-12$ storm drain system

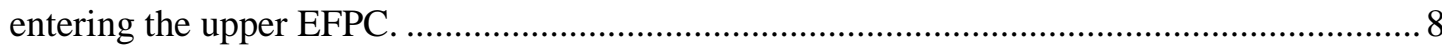

3 Concentrations of total mercury, dissolved gaseous mercury, and post-purge mercury concentrations in Outfall 200 water versus time during the 2009 in-stream mercury

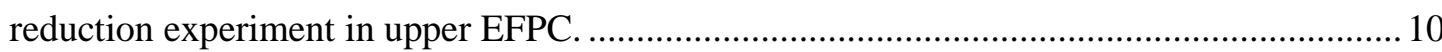

4 Sorption kinetics of $\mathrm{Hg}$ (II) by thiol- or sulfur-based resins (a) and other sorbents (b)........... 18

5 Fraction of mercury breakthrough at outlet during short-term column studies (flow

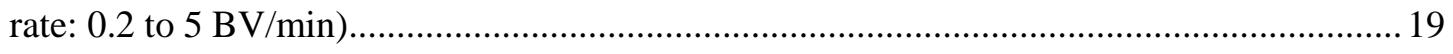

$6 \quad$ Construction cost as a function of processing flow rate and sorbent cost................................ 21

\section{LIST OF TABLES}

Table

Page

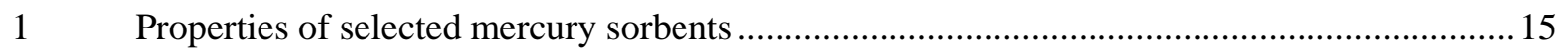

2 Technology comparison between adsorption and $\mathrm{SnCl}_{2} /$ air stripping.................................. 22 



\section{LIST OF ACRONYMS}

$\begin{array}{ll}\text { AWQC } & \text { Ambient Water Quality Criteria } \\ \text { BJC } & \text { Bechtel Jacobs Co. LLC } \\ \text { BV } & \text { bed volume } \\ \text { CVAFS } & \text { Cold Vapor Atomic Fluorescence Spectrometry } \\ \text { D\&D } & \text { Demolition and Deconstruction } \\ \text { DGM } & \text { Dissolved gaseous mercury } \\ \text { DOE } & \text { Department of Energy } \\ \text { DOM } & \text { dissolved organic matter } \\ \text { EBCT } & \text { empty bed contact time } \\ \text { EM } & \text { Environmental Management } \\ \text { EFPC } & \text { East Fork Poplar Creek } \\ \text { GAC } & \text { granular activated carbon } \\ \text { GPM } & \text { Gallons per minute } \\ \text { Hg(0) } & \text { elemental mercury } \\ \text { Hg(II) } & \text { mercury in oxidation state II } \\ \text { MCL } & \text { Maximum Concentration Limit } \\ \text { MSE } & \text { MSE Technology Applications Inc. } \\ \text { O\&M } & \text { Operation \& Maintenance } \\ \text { ORNL } & \text { Oak Ridge National Laboratory } \\ \text { ORO } & \text { Oak Ridge Operations } \\ \text { PNNL } & \text { Pacific Northwest National Laboratory } \\ \text { SAMMS } & \text { Self-Assembled Monolayer on Mesoporous Silica } \\ \text { SRS } & \text { Savannah River Site } \\ \text { TCLP } & \text { Toxicity Characteristic Leaching Procedure } \\ \text { TMDL } & \text { Total Maximum Daily Load } \\ \text { TRC } & \text { Total residual chlorine } \\ \text { U.S. EPA } & \text { U.S. Environmental Protection Agency } \\ \text { VOCs } & \text { volatile organic carbons } \\ \text { WEMA } & \text { West End Mercury Area } \\ \text { Y-12 NSC } & \text { Y-12 National Security Complex } \\ & \\ \text { ORA } & \end{array}$





\section{ACKNOWLEDGMENTS}

The research presented herein was funded by the U.S. Department of Energy's (DOE) Office of Technology Innovations \& Development (EM-30) Groundwater \& Soil Remediation Program (EM-32). Guidance regarding programmatic direction was generously provided by Karen Skubal in the DOE's EM-32 office and Elizabeth Phillips at the DOE Oak Ridge Operations (ORO) office. The authors would like to acknowledge the contribution of previous investigators to the ORNL 2008 and 2009 EM-32 project reports, which served as the basis for the analysis of chemical reduction technology in this report. Sincere thanks are given to all the ORNL EM-32 project participants, especially, Mary Anna Bogle, Baohua Gu, and Eric Pierce, who provided a critical review of this report, and Brian Lester, who did some treatment tests. Our appreciation is extended to many Environmental Sciences Division staff members, including Scott Brooks, Tonia Mehlhorn, and Xiangping Yin, who provided support for various aspects of this report. 



\section{EXECUTIVE SUMMARY}

Despite decades of efforts to reduce mercury $(\mathrm{Hg})$ contamination, low levels of mercury continue being discharged into the East Fork Poplar Creek (EFPC) from the Y-12 National Security Complex (NSC), Oak Ridge, Tennessee. This study has been carried out to address how to remove waterborne mercury at concentrations ranging from $<1$ to $\sim 40$ microgram $/ \mathrm{L}(\mu \mathrm{g} / \mathrm{L})$. This report summarizes the results of the current study and discusses waterborne mercury treatment technologies with the potential for decreasing mercury loading to the surface water of upper EFPC. The currently available waterborne mercury treatment technologies are briefly reviewed in this report. Based on the specific conditions at the Y-12 NSC, two promising treatment options are identified: chemical reduction using $\mathrm{SnCl}_{2}$ coupled with air stripping $\left(\mathrm{SnCl}_{2} /\right.$ air stripping) and sorption.

Mercury-contaminated water is collected from process water, cooling and surface runoff, and infiltrating groundwater using a storm drain system within the Y-12 NSC. The collected water emerges at Outfall 200, and is discharged to the EFPC. Field tests conducted near Outfall 200 in 2008 and 2009 showed that when water was treated with $0.12 \mu \mathrm{mol} / \mathrm{L}$ stannous tin, $\mathrm{Sn}$ (II), up to 90\% of the mercury $(\sim 1 \mu \mathrm{g} / \mathrm{L})$ in the Outfall 200 discharge was chemically reduced to $\mathrm{Hg}(0)$, after removal of residual chlorine using $3 \mu \mathrm{M}$ ascorbic acid (Southworth et al., 2010). The dissolved $\mathrm{Hg}(0)$ can be removed by air stripping, but the efficiency of this approach has yet to be evaluated. A pilot test is being designed and implemented by Y-12 NSC to address key questions such as Hg-removal efficiency by chemical reduction and by air stripping, selection of dechlorinating agents, and the fate of tin in the environment. The major advantages of the $\mathrm{SnCl}_{2}$ /air stripping system are (1) expected low cost at high flows and (2) production of minimal secondary wastes. However, there are environmental uncertainties associated with a technology such as this, which introduces tin to the ecosystem. The possibility that tin methylation will result in abiotic mercury methylation should be addressed before a full-scale implementation of this technology at the Y-12 NSC.

An alternative technology for mercury removal is sorption, which can be particularly effective at the mercury source area where the water flow is low and mercury concentration is high. Mercury adsorption by granular activated carbon (GAC) is a proven technology for treating mercury at the Y12 NSC. Additional lab sorption studies conducted here suggest that thiol-based materials (e.g., resins) can be cost-effective in removing mercury in contaminated waters. The thiol-functionalized resins have faster mercury sorption rates and potentially higher capacity than GAC, and the use of these resins will reduce the size of sorption vessel and sorbent replacement frequency. Treating the Hgcontaminated water at source areas (e.g., $\sim 40 \mu \mathrm{g} / \mathrm{L}$ ) with corresponding low flows $\left(\sim 213 \mathrm{~m}^{3} / \mathrm{d}\right.$ ) will be cost-effective. In the event that deactivation and decommissioning (D\&D) activities within Y-12 NSC change the source of mercury in the storm drain, a mobile sorption system can be built to accommodate that change and meet the emergency treatment requirement. The advantages of the sorption technology are that it has proven treatment efficiency, reliability, and little environmental uncertainties. A major disadvantage is that it produces secondary wastes. We recommend continuing the sorbent lab studies to optimize a sorption system that can be subsequently field tested for its removal efficiency at source areas. 



\section{INTRODUCTION}

At the Y-12 National Security Complex (NSC), Oak Ridge, Tennessee, past releases to the environment of a large quantity of mercury $(\mathrm{Hg})$ during the 1950s and early 1960s resulted in soil and groundwater contamination in source areas and subsequent transport of mercury into upper East Fork Poplar Creek (EFPC) leading to continuing contamination of stream water, as well as serious residual contamination of streambed sediments. The ecosystem of EFPC in Oak Ridge, Tennessee, remains contaminated with mercury despite remedial actions at Y-12 that have reduced mercury inputs into EFPC by more than $90 \%$ since remedial efforts began in the early 1980s. The mercury cleanup cost at the Y-12 Complex alone is currently estimated at $\$ 1$ billion. This estimated high cost is due to many issues, including technical as well as regulatory challenges. The technical factors include a lack of detailed, quantitative information on the distribution and extent of mercury contamination in soils and sediments, thus the volume of mercury-contaminated soil and building debris associated with remediation of Y-12 NSC is not well defined. The transport pathways connecting the contaminated soil/sediment to groundwater and surface waters are poorly known. And currently there is a lack of cost-effective remediation technologies for mercury contamination in soils, sediments, and water, and the costs associated with disposing of Hg-contaminated soils and sediments are high.

This report discusses waterborne mercury treatment technologies that are either currently available or are being developed for the purpose of decreasing mercury loading to the surface water of EFPC in order to meet the compliance goals agreed upon by DOE and the Environmental Protection Agency ( EPA). The current interim level is $200 \mathrm{ng} / \mathrm{L}$ at Station 17, where EFPC leaves the Y-12 NSC (Fig. 1). However, the ambient water quality criteria (AWQC) for mercury in Tennessee is $51 \mathrm{ng} / \mathrm{L}$, which is lower than the interim standard, and the mercury flux at Station 17 fluctuates with the amount of rainfall and can often exceed $200 \mathrm{ng} / \mathrm{L}$ interim goal during storm events; mercury is transported offsite through the storm sewer and creek sediments. Tennessee's regulatory approach through the National Pollution Discharge Elimination System (NPDES) permitting program will use EPA's 2009 methylmercury guidance for determination of water column concentrations of total mercury necessary to meet EPA fish tissue guidelines (set at a criterion of $0.3 \mathrm{mg} / \mathrm{kg}$ of mercury in fish tissue). This may drive down the total mercury concentration in water to between 1 and $10 \mathrm{ng} / \mathrm{L}$, which is well below the interim goal of $200 \mathrm{ng} / \mathrm{L}$ and the AWQC of $51 \mathrm{ng} / \mathrm{L}$.

Mercury in the headwaters of EFPC originates primarily from a discharge point (Outfall 200) that drains historic Hg-use areas and from contaminated streambed sediments throughout the upper reach of the EFPC within the Y-12 NSC. At the Y-12 site, the infrastructure of storm sewers and utilities lies within the unconsolidated and weathered bedrock zones. This infrastructure directs surface water runoff and process water flow toward the discharge point at Outfall 200. Residual mercury within the storm drain infrastructure and sediment-bound mercury in the vicinity of these drains are remobilized and transported through the storm drain network to Outfall 200 prior to entering EFPC stream. The mercury concentration and loading at Outfall 200 in 2008 and 2009 was 1000 to $1400 \mathrm{ng} / \mathrm{L}$ and 5 to $8 \mathrm{~g} / \mathrm{d}$, respectively. An investigation in April 2009 estimated the flow rate was approximately 7100 $\mathrm{m}^{3} / \mathrm{d}$ (i.e., $1300 \mathrm{gpm}$ ) at Outfall 200 (Southworth et al., 2010). 


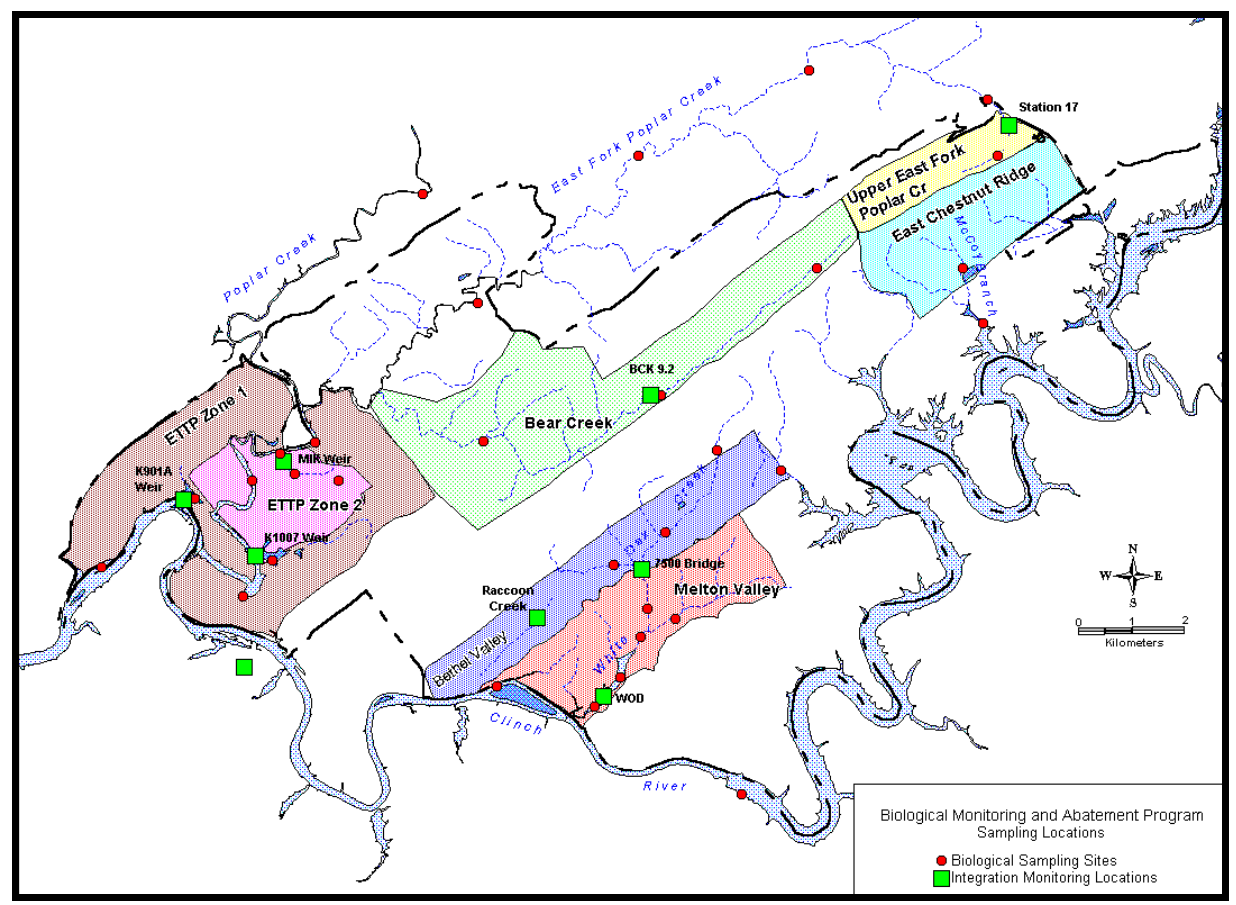

Fig. 1. Oak Ridge Reservation showing the major monitoring locations, including Station 17 along EFPC.

During 2009, an investigation intended to more closely delineate sources of mercury to the storm drain network upstream of Outfall 200 was completed (Southworth et al., 2010). This study found that the mercury flux at Outfall 200 is mainly from West End Mercury Area (WEMA). In addition, most of the baseflow mercury exported from WEMA appears to arise from a small number of relatively short sections of storm drain (Southworth et al., 2010). The concentrations of mercury in these storm drains are up to $\sim 40 \mu \mathrm{g} / \mathrm{L}$ and the flow rate is about $213 \mathrm{~m}^{3} / \mathrm{d}$ (i.e., $39 \mathrm{gpm}$ ) based on a mass balance calculation.

The chemistry of mercury in the Y-12 storm drain before exiting at Outfall 200 is unique because residual chlorine [ 2 $\mathrm{mg} / \mathrm{L}$ total residual chlorine (TRC)] from process water maintains the mercury in an oxidized inorganic $\mathrm{Hg}$ (II) form. This is in strong contrast to mercury in the surface waters of EFPC, a short distance downstream from Outfall 200, where dissolved reactive inorganic mercury becomes rapidly associated with suspended particulates, dissolved organic matter (Miller et al., 2009), the streambed bio-film, and sediments. Because oxidized inorganic mercury can undergo rapid chemical reactions with reductants, complexants, or precipitants, the system provides an exceptional opportunity for chemical treatment, such as reduction and adsorption. In previous laboratory tests, treatment of water samples collected from Outfall 200 with $\mathrm{SnCl}_{2}$ could achieve an $~ 90 \%$ reduction of $\mathrm{Hg}(\mathrm{II})$ to $\mathrm{Hg}(0)$ (Southworth et al., 2010).

The main objective of this report is to evaluate possible options for waterborne mercury treatment at the Y-12 NSC. The report provides an overview of currently available waterborne Hg-treatment technologies followed by a detailed analysis of two promising technologies. The pros and cons, the cost, and the uncertainties are analyzed for both technologies to help evaluate the selection of waterborne mercury treatment methods at the Y-12 NSC. 


\section{OVERVIEW OF WATERBORNE MERCURY TREATMENT TECHNOLOGIES}

A recent EPA report, Treatment Technologies for Mercury in Soil, Waste, and Water, summarizes currently available waterborne mercury treatment technologies and some ongoing research on innovative methods (EPA, 2007). Four broad types of water treatment methods were identified, namely, precipitation/coprecipitation, adsorption, membrane filtration, and biological treatment. Since its publication, some of the technologies described in this report have been implemented on a full-scale treatment basis at various locations, including chemical reduction with stannous tin chloride $\left(\mathrm{SnCl}_{2}\right)$ (Jackson and Looney, 2009) and sorption by thiol self-assembled monolayer on mesoporous silica (thiol-SAMMS) (Mattigod et al., 2009). This section evaluates the feasibility of all the currently available technologies based on the specific site conditions at Y-12 NSC. Two specific technologies (i.e., chemical reduction of mercury with $\mathrm{SnCl}_{2}$ and adsorption) are identified and will be discussed in greater detail in Sections 3 and 4.

\subsection{PRECIPITATION/COPRECIPITATION}

Precipitation/coprecipitation is the most commonly used process to treat Hg-contaminated wastewater (EPA, 2007). Precipitation/coprecipitation usually involves the addition of a chemical precipitant or coagulant and $\mathrm{pH}$ adjustment to convert soluble mercury species into insoluble mercury compounds. The precipitated/coprecipitated solid is then removed by clarification or filtration. The most common precipitation method used to remove mercury from wastewater is sulfide precipitation, which forms very low solubility mercury sulfide. In this process, the $\mathrm{pH}$ is adjusted to 7-9.

The advantage of precipitation/coprecipitation is that its effectiveness is minimally affected by the characteristics of the wastewater, for example, by the presence of co-contaminants. However, this technology has several drawbacks including the following: (1) production of mercury sludge, which may require further treatment or disposal as hazardous waste, (2) required adjustment of the effluent $\mathrm{pH}$, and 3) the need for skilled operators, with associated high labor costs (EPA, 2007). In some fullscale precipitation/coprecipitation systems, multiple precipitation steps and additional treatment with other technologies such as activated carbon are used to achieve the target low concentration of mercury in effluent (e.g., $<2 \mu \mathrm{g} / \mathrm{L}$ ). Precipitation/coprecipitation system may also require relatively large footprint. Therefore, this process is not well suited for waterborne mercury treatment at Y-12 NSC.

\subsection{ADSORPTION (or SORPTION)}

In an adsorption process, Hg-contaminated water is passed through a sorbent bed where mercury is adsorbed and removed from the water. The sorbent capacity of the bed is dependent on its surface area, pore size distribution, and surface chemistry. The effectiveness of adsorption is sensitive to a variety of water characteristics, such as co-contaminants and competing metals and ligands. Co-contaminant metals may outcompete mercury for sorbent surface sites, and aqueous ligands can potentially keep mercury in solution. In addition, suspended solids, organic compounds, and biological growth can cause fouling and plugging of the sorbent treatment system. After saturation, 
spent sorbents are regenerated, when possible, or replaced. In a sorption system, an equalizing tank is typically used to ensure a constant flow through the sorbent bed and enough residence time for sorption. The most common sorbents used for mercury are granular activated carbon (GAC) and resins. The advantages of the sorption technology are that it has proven treatment efficiency, reliability, and no environmental uncertainties. A major disadvantage of this technology is that it produces secondary wastes (i.e., spent sorbents).

The unique chemistry of the WEMA storm drain water makes sorption a good option for mercury removal. Total suspended solids are quite low in this water, thus making it a good candidate for sorption. In fact, Y-12 is currently using an activated carbon system to remove mercury from a spring at its Big Spring Water Treatment System, which began operation in 2005. Oak Ridge National Laboratory is also using a thiol-based resin (XUS 43604, Dow) to remove mercury from water collected by a small basement sump. Given the great promise of this technology in removing mercury from the WEMA storm drain flows, a more detailed investigation on this process was performed. The results are summarized in Section 4. Currently, we are testing a variety of sorbents for mercury removal from surrogate water in our laboratory. These results are also presented in Section 4.

\subsection{MEMBRANE FILTRATION}

Membrane filtration passes water through a semipermeable, microporous membrane to concentrate contaminants into a smaller volume of water. The pore size of the membrane is selected based on the size of the targeted mercury compounds and the pressure required for moving the wastewater through the membrane (EPA, 2007). However, suspended solids, organic compounds, colloids, and other contaminants can cause membrane fouling, causing the operating cost of membrane filtration to typically be high since a lot of energy is required to meet the pressure requirements. This would be especially true for treatment of Y-12 WEMA storm drain water given that the mercury is present primarily as $\mathrm{HgCl}_{2}$, thus having a molecular weight of $271.5 \mathrm{~g} / \mathrm{mol}$. The size of a $\mathrm{HgCl}_{2}$ molecule is on the order of nanometers. Therefore, a nanoscale pore size would have to be used to separate mercury from this water. Membrane filtration technology is often implemented after treatment by precipitation or coprecipitation to convert the dissolved mercury species to colloidal particles because dissolved mercury species are typically too small to be effectively removed by membrane filtration. Generally, the smaller the pore size, the higher the energy required to move the water through a filtration unit.

\subsection{BIOLOGICAL TREATMENT}

Biological treatment can also be used to remove mercury compounds from water. A pilot test has demonstrated the use of aerobic biological treatment to convert soluble $\mathrm{Hg}^{2+}$ to elemental mercury (Wagner-Dobler et al., 2000). The reaction is catalyzed by enzymes such as mercuric reductase. Biological treatment requires adjusting $\mathrm{pH}$ and adding amendments and nutrients to create optimal growth conditions for bacteria. However, a high concentration of chlorine in water is detrimental to the microbial activity. Biological treatment is typically used to remove high concentrations of mercury from water. To achieve the maximum concentration limit (MCL) of drinking water standard $(2 \mu \mathrm{g} / \mathrm{L})$, activated carbon was used to further treat the effluent from the biological treatment reactor. 
Biological treatment may not be well suited for removal of mercury in the WEMA storm drainage because of the presence of free chlorine and the relatively low concentration of mercury.

\subsection{CHEMICAL REDUCTION COUPLED WITH AIR STRIPPING}

This process involves using a chemical reductant, $\mathrm{SnCl}_{2}$, to reduce $\mathrm{Hg}^{2+}$ to dissolved gaseous mercury (DGM). The DGM is then removed from the water by air stripping. A full-scale $\mathrm{SnCl}_{2}$ reduction combined with an air stripping treatment system has been in operation at the Savannah River Site (SRS) since November 2007 (Jackson and Looney, 2009). The groundwater flow in this system is about 600 gpm with the concentration of mercury in the influent groundwater at about 120-150 ng/L. After treatment, the mercury concentration in the effluent is $\sim 10 \mathrm{ng} / \mathrm{L}$.

The advantages of this technology are that (1) it does not produce any liquid or solid secondary wastes, and off-gas treatment may not be required for low mercury flux, and (2) it has lower capital, maintenance, and operation costs compared to traditional treatment technologies such as sorption when treating relatively low mercury concentrations. The drawbacks of this technology are that (1) its effectiveness is affected by the presence of competing compounds (e.g., chlorine) and (2) it introduces tin to the ecosystem, which may cause tin methylation and consequently abiotic mercury methylation. The $\mathrm{SnCl}_{2}$ reduction process is not effective in removing strongly bound mercury complexes or particulate mercury. The mercury in Y-12 storm drain system is primarily in the dissolved $\mathrm{Hg}^{2+}$ ionic form at Outfall 200 and can undergo rapid reduction by $\mathrm{Sn}^{2+}$ with conversion to $\mathrm{Hg}(0)$. Air stripping can then be applied to remove the reduced mercury, that is, $\operatorname{Hg}(0)$, from the treated water. Field studies conducted in 2008 and 2009 demonstrated that the addition of $\mathrm{SnCl}_{2}$ following dechlorination (i.e., chlorine removal) was able to convert most of the $\mathrm{Hg}(\mathrm{II})$ to $\mathrm{Hg}(0)$ in the headwaters to the upper EFPC, achieving an overall conversion rate of $\mathrm{Hg}(\mathrm{II})$ to $\mathrm{Hg}(0)$ of $92 \%$ during the 2009 study (Southworth et al., 2009, 2010). Unlike the SRS site where the mercury contamination occurs in groundwater, mercury-contaminated water at the Y-12 site carries a large amount of residual chlorine, and the concentration of mercury is also 10 times higher than that at SRS. The use of higher concentrations of tin may have unknown effects to the EFPC ecosystem. For example, tin can undergo methylation to form methyl tin in stream sediment, and methyl tin can further react with mercury to form methyl mercury. The details of the field tests and the unknowns associated with the introduction of tin into EFPC will be further discussed in Section 3. 


\section{WATERBORNE MERCURY REMOVAL BY CHEMICAL REDUCTION}

\subsection{BACKGROUND}

Chemical reduction by $\mathrm{SnCl}_{2}$ is widely used in mercury analysis, in which $\mathrm{Hg}$ (II) is reduced to gaseous mercury, $\operatorname{Hg}(0)$, which is then detected and quantified by methods such as Cold Vapor Atomic Fluorescence Spectrometry (CVAFS). Using $\mathrm{SnCl}_{2}$ to remove $\mathrm{Hg}$ (II) (especially trace amounts of mercury) from wastewater was first conceived by Southworth et al. (1996). Field tests demonstrated that stannous tin $\left(\mathrm{Sn}^{2+}\right)$ was capable of converting dissolved $\mathrm{Hg}(\mathrm{II})$ to dissolved elemental mercury, $\operatorname{Hg}(0)$ in one of the outfalls (Outfall 51) within the Y-12 complex. The key findings from the 1996 study were that (1) about four to five times more stoichiometrical $\mathrm{Sn}^{2+}$ than $\mathrm{Hg}$ (II) (Sn/Hg ratio 5) was required to convert the available inorganic mercury to $\mathrm{Hg}(0)$, indicating that the reduction of $\mathrm{Hg}(\mathrm{II})$ by $\mathrm{SnCl}_{2}$ is favorable, given the wastewater chemistry of Outfall 51, and (2) an air/liquid ratio of 20 was sufficient to strip all of the resulting $\operatorname{Hg}(0)$. The study also indicated that the same chemical reduction might be applied to convert $\mathrm{Hg}(\mathrm{II})$ to $\mathrm{Hg}(0)$ in the storm drain discharge at Outfall 200 after removal of residual chlorine (Southworth, 1997). An experiment was subsequently conducted at the headwater of the EFPC, at a location immediately downstream of Outfall 200. A forced aeration was not planned in the test; rather, the test was to evaluate whether the dissolved $\mathrm{Hg}(0)$, which had been chemically converted from $\mathrm{Hg}(\mathrm{II})$, could be volatilized to the atmosphere through the shallow, turbulent $2.5 \mathrm{~km}$ reach of the EFPC between Outfall 200 and Station 17 at the Y-12 Plant boundary. However, the experiment failed to show that $\operatorname{Hg}(0)$ was produced effectively by the method (Southworth, 1997), and the cause of this failure was never positively determined. However, because $\mathrm{Sn}^{2+}$ is a strong reducing agent, it was thought that $\mathrm{Sn}^{2+}$ likely reacted with the available dissolved oxygen and other ephemeral oxidants produced by photochemical reactions in the open channel of EFPC before it could reduce $\mathrm{Hg}$ (II) in the stream. Another potential reason for this failure, resulting from the addition of $\mathrm{SnCl}_{2}$ outside the storm drain network, is the effect of flow management water (lake water), which is introduced just downstream of Outfall 200. This water introduced natural organic matter to the system, which could have reduced the efficiency of $\mathrm{Hg}(\mathrm{II})$ reduction by $\mathrm{SnCl}_{2}$. Further pursuit of $\mathrm{SnCl}_{2}$ reduction combined with in situ volatilization as the mercury removal strategy near Outfall 200 was discontinued in the late 1990s.

During early 2000, the concept was taken up and applied to the mercury-contaminated groundwater at SRS (Looney et al., 2000). Unlike the Y-12 NSC site, the SRS groundwater source contained levels of mercury that were one order of magnitude lower [ 138 ng/L as Hg(II)] than those of Outfall 200. The contaminated water chemistry was also different, with residual chlorine being absent. For the mercury-contaminated groundwater, the SRS results showed that the removal of mercury varied with $\mathrm{SnCl}_{2}$ dose. At low reagent doses, with $\mathrm{Sn}: \mathrm{Hg}$ stoichiometric ratios $<1$, little removal of $\mathrm{Hg}(\mathrm{II})$ was observed. At high reagent doses, with Sn:Hg stoichiometric ratios greater than $\sim 5-25$, tests showed relatively complete removal of $\mathrm{Hg}(\mathrm{II})(\sim 94 \%)$ and the final mercury concentrations were $<10 \mathrm{ng} / \mathrm{L}$. The data indicated that the reduction of $\mathrm{Hg}(\mathrm{II})$ was highly favored and that $\mathrm{SnCl}_{2}$ efficiently targeted $\mathrm{Hg}$ (II) in the presence of competing reactions. The kinetics study indicated that the reduction of $\mathrm{Hg}(\mathrm{II})$ to $\mathrm{Hg}(0)$ by $\mathrm{SnCl}_{2}$ was rapid and that mercury removal appeared to be controlled by the purging process; that is, removing $\mathrm{Hg}(0)$ from water facilitated the conversion of $\mathrm{Hg}(\mathrm{II})$ to $\mathrm{Hg}(0)$. At 
SRS, an air-stripping system for removal of volatile organic carbons (VOCs) from groundwater has been in operation since 1985. Therefore, the removal of mercury could be achieved by simply adding low levels of $\mathrm{SnCl}_{2}$ into the air stripping system. The full-scale $\mathrm{SnCl}_{2}$ reduction coupled with air stripping at SRS has been in operation since November 2007 (Jackson and Looney, 2009). The water flow in this system is about $3270 \mathrm{~m}^{3} / \mathrm{d}$ (i.e., $600 \mathrm{gpm}$ ), and the concentration of mercury in the influent groundwater varies from 120 to $150 \mathrm{ng} / \mathrm{L}$. After treatment, the mercury concentration in the effluent is $\sim 10 \mathrm{ng} / \mathrm{L}$.

At the Y-12 NSC, although chemical reduction combined with in situ volatilization did not succeed in sunlight-illuminated surface water, as demonstrated in the late 1990s, the application of this technology within the enclosed storm drain network was proposed for additional tests (Southworth et al., 2009, 2010). The hypothesis was that within the enclosed storm drain system, residual chlorine would be removed through dechlorination and the production of additional oxidants associated with photochemistry would be avoided, thus increasing the effectiveness of $\mathrm{Sn}^{2+}$ for reducing $\mathrm{Hg}^{2+}$. The resulting $\mathrm{Hg}(0)$, however, would still need to be volatilized from water to air with forced aeration. Following the approval of the concepts, field tests of the in situ conversion of $\operatorname{Hg}(\mathrm{II})$ to $\operatorname{Hg}(0)$ in the headwaters of EFPC were conducted in 2008 and 2009 using $\mathrm{SnCl}_{2}$ as a chemical reductant and various chemicals as dechlorinating agents (e.g., thiosulfate and ascorbic acid). The details of these two studies will be summarized and discussed in Section 3.3.

\subsection{THE CHEMISTRY OF Hg(II) REDUCTION}

It is well known that $\mathrm{Hg}^{2+}$ has a strong tendency to form complex with hydroxyls, chloride, and organic compounds. Due to the unique chemistry of the storm drain water at Outfall 200, mercury may be present primarily as $\mathrm{HgCl}_{2}$, which can be easily reduced by $\mathrm{SnCl}_{2}$ according to the following half-cell reactions:

$$
\begin{array}{ll}
\mathrm{Sn}^{4+}+2 \mathrm{e}^{-} \rightarrow \mathrm{Sn}^{2+} & \mathrm{E}^{0}=+0.16 \mathrm{~V} \\
\mathrm{Hg}^{2+}+2 \mathrm{e}^{-} \rightarrow \mathrm{Hg}^{0} & \mathrm{E}^{0}=+0.85 \mathrm{~V}
\end{array}
$$

Note that $\mathrm{SnCl}_{2}$ reduction is not effective in removing strongly bound mercury complexes (e.g., HgDOM complex) or particulate mercury. However, in addition to $\mathrm{Hg}^{2+}, \mathrm{SnCl}_{2}$ can reduce other dissolved constituents in the storm drain water such as dissolved oxygen, nitrate, and chlorine according to the following half-cell reactions (Bard et al., 1985):

$$
\begin{array}{cl}
2 \mathrm{HClO}+2 \mathrm{H}^{+}+2 \mathrm{e}^{-} \rightarrow \mathrm{Cl}_{2}(\mathrm{~g})+2 \mathrm{H}_{2} \mathrm{O} & \mathrm{E}^{0}=+1.63 \mathrm{~V} \\
\mathrm{O}_{2}(\mathrm{aq})+4 \mathrm{H}^{+}+4 \mathrm{e}^{-} \rightarrow 2 \mathrm{H}_{2} \mathrm{O} & \mathrm{E}^{0}=+1.27 \mathrm{~V} \\
\mathrm{NO}_{3}^{-}+2 \mathrm{H}^{+}+2 \mathrm{e}^{-} \rightarrow \mathrm{NO}_{2}^{-}+\mathrm{H}_{2} \mathrm{O} & \mathrm{E}^{0}=+0.83 \mathrm{~V}
\end{array}
$$

Thermodynamically, dissolved oxygen and chlorine are stronger oxidizers and compete with $\mathrm{Hg}(\mathrm{II})$ for $\mathrm{Sn}^{2+}$, which may result in a substantially higher dose requirement of $\mathrm{SnCl}_{2}$ than for stoichiometric reduction of mercury. This is consistent with results from previous studies, which showed that a Sn:Hg ratio of 4-25 was necessary to achieve significant reduction of $\mathrm{Hg}$ (II) (Southworth et al., 1997; Looney et al., 2000).

To enhance the efficiency of mercury reduction and lower the $\mathrm{SnCl}_{2}$ consumption, chemicals need to be added to remove competing reagents first. This step is also necessary to minimize the introduction 
of excessive tin into the environment. Residual chlorine is present in concentrations up to $\sim 2 \mathrm{mg} / \mathrm{L}$ or $0.028 \mathrm{mM}$ in Y-12 WEMA storm drain water, which is 5,600 times higher than the amount of $\mathrm{Hg}$ (II) in the water. This excess amount of chlorine would consume the added Sn(II) before it reacts with Hg(II). The 2008 and 2009 field studies tested the ability of various compounds such as thiosulfate and ascorbic acid to act as dechlorinating agents for the removal of chlorine from the treated waters.

\subsection{STANNOUS CHLORIDE REDUCTION FIELD TESTS}

\subsubsection{Field Test}

Mercury reduction experiments were conducted $\sim 64 \mathrm{~m}$ upstream of Outfall 200, where a grating above junction box 200a6 was utilized as a portal for introducing reductant to the mercury source water, as shown in Fig. 2 (Southworth et al., 2009). Three field trials were conducted in November 2008. In all the experiments, sodium thiosulfate $\left(\mathrm{Na}_{2} \mathrm{~S}_{2} \mathrm{O}_{3} \cdot 5 \mathrm{H}_{2} \mathrm{O}\right)$ was selected as a dechlorinating agent because of its high efficiency for removing $\mathrm{Cl}_{2}$ and its low toxicity to biota. We noted that a dechloration unit had been placed right before Outfall 200, which adds ammonium bisulfate into the water as needed to removal residual chlorine. However, dechlorination was required for the mercury reduction experiments since the trials were conducted upsteam of the dechlorination unit. Ammonium bisulfate was not selected as a dechlorinating agent for the reduction tests because laboratory tests indicated that it strongly interfered with the reduction of $\mathrm{Hg}$ (II) with $\mathrm{SnCl}_{2}$ (Southworth et al., 2009). Extra loading of ammonium bisulfate could also potentially deplete the dissolved oxygen in upper EFPC water.

In the first field trial, the target concentrations of thiosuflate and Sn(II) were $10 \mathrm{mg} / \mathrm{L}$ and $20 \mu \mathrm{g} / \mathrm{L}$, respectively, and they were added simultaneously to the junction box. In the second field test, the target concentration of $\mathrm{Sn}(\mathrm{II})$ was reduced to $10 \mu \mathrm{g} / \mathrm{L}$ with other conditions remaining the same. During these trials, an increase in total Hg was observed in the water collected at Outfall 200. In the third field experiment, sodium thiosulfate was added to the drainage water first and run for 1 hour before adding the stannous chloride solution. The purpose of this study was to test the hypothesis that thiol ligands for dechlorination may have mobilized mercury in the drainage structure, which would explain the increase in total Hg concentration at Outfall 200 that was observed in the first two trials.

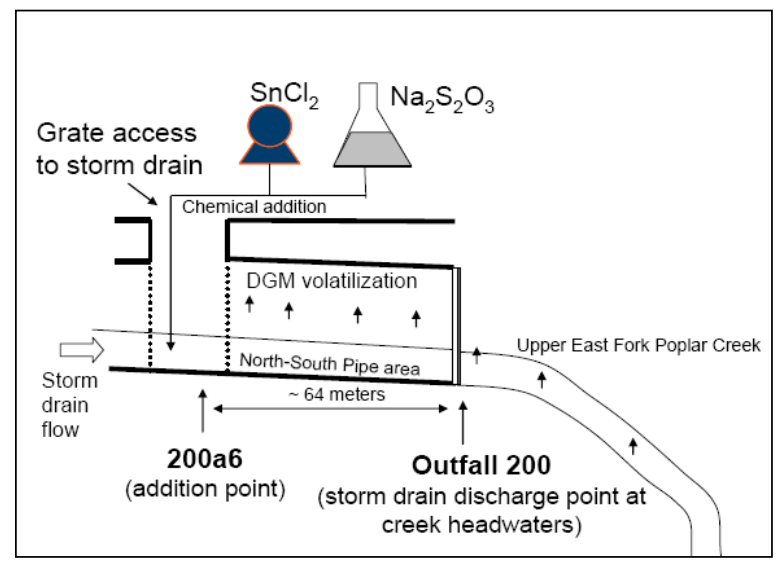

Fig. 2. Schematic of the $\mathrm{SnCl}_{2}$ chemical reduction field test in the $\mathbf{Y}-12$ storm drain system entering the upper EFPC. 
The key findings from this series of field tests in 2008 included the following: (1) a conversion of $330 \mathrm{ng} / \mathrm{L} \mathrm{Hg}(\mathrm{II})$ to $\mathrm{Hg}(0)$ in Outfall 200 water or approximately $30 \%$ of the baseline total mercury concentration was achieved when $20 \mu \mathrm{g} / \mathrm{L} \mathrm{SnCl}_{2}$ and $10 \mathrm{mg} / \mathrm{L}$ sodium thiosulfate were used; (2) when the concentration of Sn(II) was reduced from 20 to $10 \mu \mathrm{g} / \mathrm{L}$ (molar ratio of $\mathrm{Sn} / \mathrm{Hg}$ of $\sim 32$ ), reduction efficiency decreased $(\mathrm{Hg}(0)=198 \mathrm{ng} / \mathrm{L})$ in Outfall 200 water; and (3) the concentration of total mercury at Outfall 200 increased from $1060 \mathrm{ng} / \mathrm{L}$ to $1810 \mathrm{ng} / \mathrm{L}$ during the tests, which was thought to be caused by the mobilization of mercury in the drainage system by thiosulfate. Taken together, the stannous tin needed to convert $\mathrm{Hg}(\mathrm{II})$ to $\mathrm{Hg}(0)$ was higher in the field than in the laboratory test, with a molar ratio of $\mathrm{Sn} / \mathrm{Hg}$ of $\sim 30$.

\subsubsection{Field Test}

The 2009 effort focused on solving two shortcomings of the 2008 study, that is, the temporary mobilization of mercury from drainage pipe walls by thiosulfate and the relatively low fraction of $\mathrm{Hg}(\mathrm{II})$ converted to dissolved gaseous mercury, $\mathrm{Hg}(0)$. To this end, various alternative dechlorinating (reducing) reagents were examined in the laboratory including ascorbic acid, sodium sulfite, sodium borohydride, hydroxylamine hydrochloride, and hydrogen peroxide. Alternate stabilizing agents for $\mathrm{SnCl}_{2}$ solubility other than acid and alternate reducing agents for $\mathrm{Hg}(\mathrm{II})$ other than $\mathrm{SnCl}_{2}$ were also examined. Based on laboratory results, ascorbic acid was chosen to replace thiosulfate as the dechlorinating agent in field tests in order to reduce the mobilization of mercury from solid surfaces within the storm drain system.

The low conversion efficiency during the 2008 study was assumed to be a result of the simultaneous addition of reductant and dechlorinating agents, which may have allowed some residual chlorine or dissolved oxygen to consume part of the $\mathrm{Sn}^{2+}$ before it had a chance to react with $\mathrm{Hg}$ (II). During the 2009 field test, ascorbic acid was added at a location $250 \mathrm{~m}$ upstream of 200a6 (Fig. 2.) at Outfall 150, a short distance upstream from where it joins the main storm drain that exits at Outfall 200. The vendor recommendation of $2.5 \mathrm{mg}$ of ascorbic acid per $\mathrm{mg}$ of $\mathrm{Cl}_{2}$ (1:1 molar ratio) was used to calculate the addition rate. Although variable with $\mathrm{pH}$, at $\sim$ neutral $\mathrm{pH}$, ascorbate has a very low reducing potential ( $\mathrm{E}^{0} \sim-0.08 \mathrm{~V}$ ) (Borsook and Keighley, 1933). Thus, it is easily oxidized and is used as a reductant in many applications as well as a preservative. In our test, ascorbic acid was also added to $\mathrm{SnCl}_{2}$ to stabilize $\mathrm{Sn}^{2+}$ added at 200a6. The target concentration for $\mathrm{Sn}$ (II) at Outfall 200 was the same as that in the 2008 experiments, $20 \mu \mathrm{g} / \mathrm{L}(0.17 \mu \mathrm{M})$, thus the molar ratio of $\mathrm{Sn} / \mathrm{Hg}$ of $\sim 32$. Figure 3 shows the evolution of total mercury, dissolved gaseous mercury, and post-purge mercury concentrations in Outfall 200 water versus time during the 2009 in-stream mercury reduction experiment in the upper EFPC.

Key findings from the 2009 field test included the following: (1) conversion of $\mathrm{Hg}(\mathrm{II})$ to $\mathrm{Hg}(0)$ was $>90 \%$ at Outfall 200 during the field study; (2) ascorbic acid was as effective as thiosulfate and sulfite in dechlorination; (3) ascorbic acid did not mobilize sorbed mercury from the storm drain system; (4) ascorbic acid was also effective in stabilizing $\mathrm{SnCl}_{2}$ to prevent its precipitation; (5) the tested dechlorinating and reducing agents did not significantly affect the dissolved oxygen and $\mathrm{pH}$ of the stream water and exhibited low toxicity; (6) ascorbic acid partially converted $\mathrm{Hg}(\mathrm{II})$ to $\mathrm{Hg}(0)$ in the field study (no reduction was observed in lab studies); (7) reoxidation of $\operatorname{Hg}(0)$ during air 
stripping was minimal, and (8) natural evasion of $\mathrm{Hg}(0)$ from the turbulent flow of EFPC downstream from Outfall 200 was not effective at purging the $\mathrm{Hg}(0)$ from the water.

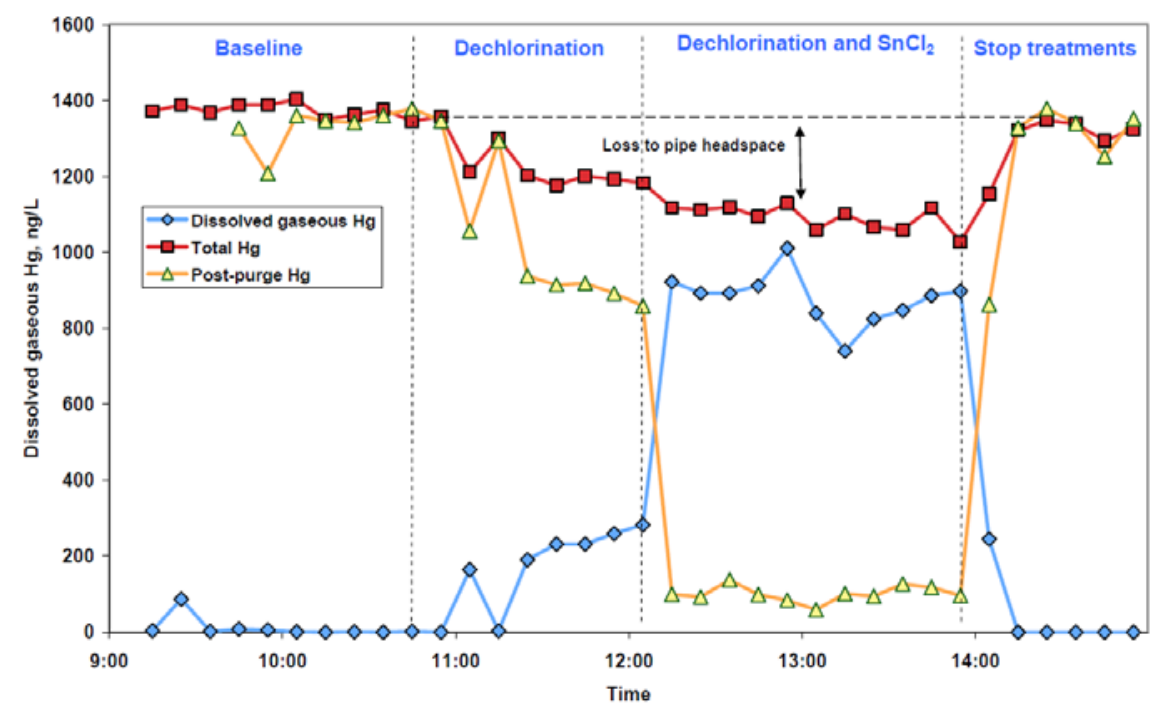

Fig. 3. Concentrations of total mercury, dissolved gaseous mercury, and post-purge mercury concentrations in Outfall 200 water versus time during the 2009 in-stream mercury reduction experiment in upper EFPC.

\subsubsection{Engineering Implication of the Field Studies}

Findings of the 2008 and 2009 studies indicate that chemical reduction combined with an engineered air-stripping system has the potential to remove a significant fraction of the waterborne mercury in the storm drain system at Y-12 NSC. Passive evasion does not provide significant $\mathrm{Hg}(0)$ removal. Since the dechlorination and $\mathrm{SnCl}_{2}$ addition would occur at Outfall 200 and not in the storm drain system, mobilization of the mercury from solid surfaces within the storm drain would not be an issue. Currently, ammonium bisulfate is being used to dechlorinate the water just upstream of Outfall 200. This system potentially could continue to provide the dechlorination. However, questions remain as to whether ammonium bisulfate added from the plant dechlorination unit would interfere with the mercury reduction in the air-stripping system by $\mathrm{SnCl}_{2}$. Ascorbic acid can still be used as a stabilizing agent for $\mathrm{SnCl}_{2}$ solution if it can provide better mercury reduction.

As noted above, the 2008 and 2009 studies were performed in the storm drainage system. Going from this setting to an engineered system, a number of questions need to be addressed before a fullscale system can be designed. Subject to question are (1) choice of $\mathrm{SnCl}_{2}$ stabilization agents and/or dechlorinating agents; (2) gas/liquid ratio to provide efficient $\mathrm{Hg}(0)$ removal; (3) Hg-removal efficiency; (4) effects of storm water chemistry and particle-associated mercury; and (5) speciation and concentration of tin in the effluent. Therefore, a pilot-scale air-stripping system should be installed first to address these questions and thus reduce the possible risks. 


\subsection{COST ANALYSIS}

If implemented, the air-stripping system will treat $7000 \mathrm{~m}^{3} / \mathrm{d}$ of storm drain water at Outfall 200 . Using the 2008 results, the target concentrations of thiosulfate and $\mathrm{Sn}(\mathrm{II})$ will be $10 \mathrm{mg} / \mathrm{L}$ and $20 \mu \mathrm{g} / \mathrm{L}$, respectively, for removal of $\mathrm{Hg}(\mathrm{II})$ at $\sim 90 \%$ efficiency. These target concentrations correspond to consumption of thiosulfate and $\mathrm{Sn}$ (II) at $154 \mathrm{lb} / \mathrm{d}$ and $0.31 \mathrm{lb} / \mathrm{d}$, respectively. The chemical costs per day can be calculated to be $\$ 28$ for thiosulfate (based on unit price of $\$ 400 /$ metric ton for sodium thiosulfate, www.alibaba.com) and $\$ 21$ for $\mathrm{SnCl}_{2}$ (based on unit price of $\$ 150 / \mathrm{kg}$ for $\mathrm{SnCl}_{2} \cdot 2 \mathrm{H}_{2} \mathrm{O}$, Looney et al., 2000). Therefore, the chemical cost is insignificant. MSE Technology Applications (MSE) estimated that an air-stripping system would cost $\sim \$ 1.6$ million to install. Total cost was expected to be around \$2.2 million to begin daily operation of the full-scale system. Looney et al. (2000) conservatively estimated the operation cost of $\mathrm{SnCl}_{2}$ reduction coupled with an air-stripping system to be $<\$ 0.3 / \mathrm{m}^{3}$ of treated water. If a Chemical Engineering Index of 3\% is considered from 2000 to 2010, the current treatment cost could be as high as $\$ 0.4 / \mathrm{m}^{3}$. Therefore, the O\&M (operation and maintenance) cost could be $\sim \$ 1.0$ million/year. It is important to note that if the mercury sources in the storm drain system are not cleaned out, this operational cost will continue for a long time.

\subsection{UNCERTAINTIES ASSOCIATED WITH FULL-SCALE IMPLEMENTATION}

There are many uncertainties associated with the implementation of a full-scale $\mathrm{SnCl}_{2} /$ air-stripping system. Some of these uncertainties are described as follows.

- Tin speciation, methylation, and resulting impacts. Tin would be loaded to the creek at a rate of $0.31 \mathrm{lb} / \mathrm{d}$ (or $140 \mathrm{~g} / \mathrm{d}$ ). Diverting the flow augmentation water added just downstream of Outfall 200 has been discussed as a means to reduce mercury flux to the surface waters in upper EFPC although there are no current plans in place for this to occur. A dilution of the Sn(II) with upper EFPC would occur as a result of this flow augmentation water. The implications to Sn(II) accumulation in the system would need to be considered regarding the diversion of flow augmentation water downstream. If $\mathrm{Sn}(\mathrm{II})$ is not precipitated as stannous hydroxide, the $\mathrm{Sn}$ concentration could exceed the required $5 \mu \mathrm{g} / \mathrm{L}$ at the regulatory monitoring station C11. It is currently unknown in what form (although the majority is expected to be precipitated) and concentration $\mathrm{Sn}$ in the stream will exist and whether it will be bioavailable. Tin is subject to microbial methylation in anaerobic sediments (Gilmour et al., 1987), and methyltin compounds have been detected in both freshwater and saltwater, with high-salinity waters generally having higher concentrations of methyltin. Methyltin is capable of reacting with dissolved $\mathrm{Hg}$ (II) to form methylmercury (Hamasaki et al., 1995; Celo et al. 2006), thus raising concerns that the introduction of inorganic Sn to a Hg-contaminated system could enhance the generation of methylmercury. At the very least, a tin speciation modeling should be performed based on the environmental conditions of the EFPC.

- Effect of additional dechlorinating agents on mercury methylation. The 2008 study showed that thiosulfate can mobilize the sorbed mercury from the storm drain pipe. It is unclear whether the unreacted thiosulfate will desorb mercury from sediment and particles and make this mobilized mercury more bioavailable. On the other hand, ascorbic acid as a dechlorinating agent is expensive and adds an additional carbon source to the creek, which possibly promotes the methylation of mercury in the creek. 


\section{WATERBORNE MERCURY REMOVAL BY SORPTION}

\subsection{INTRODUCTION}

The survey conducted in 2009 found that most of the baseflow mercury at Outfall 200 is exported from the West End Mercury Area (WEMA) and appeared to arise from a small number of relatively short sections of storm drain (Southworth et al., 2010). Therefore, if mercury-removal systems could be placed in these storm drain sections, the discharge of mercury into EFPC could be significantly reduced. For a relatively long-term operation, these units should possess the following essential features: (1) they can effectively remove waterborne mercury at relatively low concentrations (e.g., $<0.1 \mathrm{mg} / \mathrm{L}$ ); (2) they do not add chemicals to the natural stream system; and (3) they are costeffective. Among currently available mercury removal technologies (EPA, 1997; EPA, 2007), adsorption and ion exchange are simple processes and appear to be feasible options to meet the above requirements. In addition, if the storm drain water can be treated in a passive way, the operational costs can be significantly reduced. In the following sections, the leading sorbents, especially commercial products for $\mathrm{Hg}^{2+}$ removal, are briefly reviewed.

Sorption is the simplest method to remove mercury from water and can be accomplished either by physical attraction between adsorbates and adsorbents or by chemical reactions between them. The removal of mercury from water by adsorption has been extensively investigated by using various kinds of adsorbents such as activated carbon (Natale et al., 2006), chitosan (Miretzky and Cirelli, 2009), mesoporous silica (Walcarius and Delacote, 2005), natural and synthetic materials (Herrero et al., 2005; Chiarle et al., 2000; Bailey et al., 1999) and low-cost waste tire rubber (Tharin, 1974). Among these, traditional natural ion-exchange materials, such as zeolites (Blanchard et al., 1984) and clays (Benhammou et al., 2005), and adsorbents like activated carbon, and waste tire rubber suffer from low selectivity and weak binding affinity for $\mathrm{Hg}^{2+}$. To improve the performance of activated carbon for mercury removal, sulfur-impregnated carbon was produced and applied in industrial wastewater treatment (e.g., Mersorb ${ }^{\circledR}$ ) (Tonini et al., 2004). In recent years, attention has been paid to functionalized clays (Lagadic et al., 2001), resins (Chiarle et al., 2000), organoceramics (Nam and Tavlarides, 2003), and mesoporous silicates (Feng et al., 1997; Chen et al., 1999) with functional groups such as thiol groups.

The thiol-functionalized materials have specific and strong binding ability toward $\mathrm{Hg}^{2+}$ as a consequence of a soft Lewis acid-soft Lewis base interaction. The thiol-functionalized mesoporous molecular sieves have attracted particular attention because the large uniform pore structure of these materials greatly facilitates the access of the metal ions to the thiol binding sites, resulting in improved metal-loading capacities. One successful example of these materials is self-assembled monolayers on mesoporous supports (SAMMS), developed by Pacific Northwest National Laboratory (PNNL) (Feng et al., 1997; Chen et al., 1999) and now commercialized by Steward Environmental Solutions. The reported maximum mercury sorption capacity of SAMMS is $613 \mathrm{mg} / \mathrm{g}$, and the sorption of $\mathrm{Hg}$ (II) can be completed in minutes (Chen et al., 1999). 
Chitosan has also been a focus of study for mercury removal. Chitosan is a low-cost biosorbent with excellent mercury removal capacity due to its large number of $-\mathrm{NH}_{2}$ groups, which can strongly bind with mercury in near-neutral solutions. Shafaei et al. (2007) reported that decreasing the particle size of chitosan increased the amount of mercury removal, achieving the maximum mercury uptake by chitosan $(0.177 \mathrm{~mm})$ at $1127 \mathrm{mg} \mathrm{Hg} / \mathrm{g}$ chitosan. However, natural flake and powder forms of chitosan are not suitable for use in industrial-scale applications because the nonporous chitosan will cause a large pressure drop in a flow-through column. To solve this problem, many methods have been developed. For example, chitosan beads with high porosity and surface area have been made by dissolving the chitosan in acetic acid, followed by dropping the solution into a casting bath of base (Rorrer et al., 1993). The chitosan beads can be further functionalized with thiol groups to enhance the mercury adsorption capacity (Merrifield et al., 2004). The fine chitosan particles can also be immobilized in porous support media to produce an adsorbent that can maximally keep the mercury adsorption capacity of chitosan (Chang et al., 2007). Excellent reviews on removal of metal ions, especially mercury, using chitosan and its derivatives, can be found in Bailey et al. (1999), Miretzky and Cirelli (2009), and Varma et al. (2004).

Ion exchange resins are efficient in removing trace amounts of mercury from aqueous phase. To maximize the removal of mercury, chelating ion exchangers, such as thiol-functionalized resins, are typically used. This is because cation or anion exchangers without strong chelating ability are vulnerable to complexation of $\mathrm{Hg}^{2+}$ in the water. Among the tested commercial chelating resins, Duolite GT-73 from Rohm and Haas (now a subsidiary of Dow) stands out as the most investigated one and has exhibited good mercury adsorption capacity (Ritter and Bibler, 1992). In a DOE report evaluating selective ion exchange resins for removal of ppb levels of mercury from groundwater, seven resins were studied including cation exchanger CG8 (Resin Tech), anion exchanger Dowex 21K (Dow), cation exchanger containing thiol functional groups GT 73 and SR-4 (Sybron Chemical), chelating resin Chelex 20, and Hg-specific chelating resin SIR-200 (Resin Tech) and S-920 (Purolite) (Monson et al., 2000). SR-4 and SIR-200 performance was similar to that of Duolite GT-73. GT-73 is now replaced by GT-74 from Rohm and Haas and Dowex XUS 43604 from Dow in the North America market. XUS was tested for removal of mercury from a surrogate sump water at ORNL along with Lewatit TP 214 resin (with thiourea functional groups) and showed a slightly better performance in column tests and stronger affinity for mercury during Toxicity Characteristic Leaching Procedure (TCLP) tests (MSE, 2008).

Hollerman et al. (1999) performed a mercury sorbent test at Outfall 200 at the Y-12 NSC and demonstrated that sorbents SIR-200, KeyleX (SolmeteX), and GT-73 were the best materials tested for removal of mercury from upper EFPC among eight tested sorbents, including GAC Filtrasorb 300 (Calgon Carbon), SR-4, S-920, Forager Sponge, and Mersorb ${ }^{\circledR} 1.5 \mathrm{~mm}$. KeyleX is a polyacrylate resin coated with proprietary polymer and thiol functional groups, making it mercury specific. The manufacturer recommended that the water be pretreated with chlorine, hypochlorite, or chlorinated dioxide to $1-2 \mathrm{mg} / \mathrm{L}$ to ensure that the mercury is in ionic state. Manufacturers of polystyrene/divinylbenzene resins such as GT-73, however, specifically recommend removing such oxidizers prior to contact. According to the manufacturer SolmeteX, KeyleX has a mercury adsorption capacity of $3.4 \mathrm{eq} / \mathrm{L}$, which is much higher than that of other resins (e.g., $1.3 \mathrm{eq} / \mathrm{L}$ for GT73). The Forager Sponge, by Dynaphore, Inc., is an open-cell cellulose sponge incorporating an amine-containing polymer that has selectivity for both cationic and anionic species of mercury and 
other heavy metals. The sponge has the advantage of little impedance to flow of water and can be easily applied in situ to remove mercury from the water in a passive manner. The poor performance of the Forager Sponge in the Hollerman et al. study (1999) may be a result of free passing of particulate mercury $(<1 \mu \mathrm{m})$ through the Forager Sponge. The particulate mercury may be filtered out by resin or activated carbon beds.

Lloyd-Jones et al. (2004) compared GT-73 with Purolite S-920 containing isothiouronium functional groups and showed that Purolite S-920 has much faster mercury adsorption kinetics but lower capacity than GT-73 at pH between 4 and 6. They believed that the sorption of mercury to GT-73 was mainly through cation exchange while the sorption to S-920 was mainly through complexation with the isothouronium functional group, which may have caused the observed difference. Commercial resins with isothiouronium functional groups also include Ionac SR-3 (Sybron Chemical) and SIR-400 (Resin Tech). In addition, GT-73 showed the ability to be regenerated by acid treatment, whereas spent S920 and Lewatit TP 214 could not be regenerated, but the Hg-loaded spent materials were able to pass the EPA TCLP test (Fondeur et al., 2002).

To summarize the previous studies, SIR-200, GT-73, and KeyleX stand out as the best commercial resins for mercury removal. Among these three, GT-73 can be efficiently regenerated by concentrated hydrochloric acid, while SIR-200 can only be partially regenerated, and KeyleX cannot be regenerated.

Another potential low-cost material for mercury removal is layered metal sulfides, which have been developed recently by Manos and Kanatzidis (2009). The layered sulfide material $\mathrm{K}_{2 x} \mathrm{Mn}_{\mathrm{x}} \mathrm{Sn}_{3-x} \mathrm{~S}_{6}$ $(x=0.5-0.95)$ (KMS-1) can quickly remove mercury from water in minutes at a wide $\mathrm{pH}$ range (2.59) and has a capacity of $377 \mathrm{mg} \mathrm{Hg} / \mathrm{g}$. In addition, KMS-1 is stable in atmosphere and water. The particle size of KMS-1 and SAMMS are typically $<5 \mu \mathrm{m}$. In order to use these high-efficiency materials in industrial-scale applications, immobilizing them in porous support media is necessary.

\subsection{LABORATORY SORPTION STUDIES}

The objectives of sorption studies conducted at ORNL during 2010 were (1) to screen, in terms of mercury loading capacity and kinetics, the commercially or near commercially available sorbents for removal of low-concentration mercury from the Y-12 storm drain and (2) to evaluate the leachability and regeneration of the spent sorbents.

\subsubsection{Materials and Methods}

\subsubsection{Materials}

The selection of commercially available resins for this study is based on a review of previous studies. The properties of some selected resins and sorbents are summarized in Table 1. Granular activated carbon from Calgon Carbon was used as a base sorbent.

SAMMS, both in powder and granular forms, were obtained from Steward Environmental Solution. KMS-1 was provided by Northwestern University. In order to use KMS-1 in the column test, the KMS-1 powder was immobilized in alginate beads using the method reported by Chang et al. (2007). 
Briefly, $5 \mathrm{~g}$ of sodium alginate was dissolved in $250 \mathrm{~mL}$ of deionized (DI) water and mixed with $2 \mathrm{~g}$ of KMS-1 powder. After a 30 min. sonication, the alginate KMS-1 mixture was then added drop by drop into a stirred $10 \% \mathrm{CaCl}_{2}$ solution. By doing so, the water-soluble sodium alginate is converted into water-insoluble calcium alginate beads. The beads were washed with DI water several times to remove $\mathrm{CaCl}_{2}$ from the bead surface and stored at $4^{\circ} \mathrm{C}$ before use. All the adsorbents except KMS- 1 and powder SAMMS were conditioned in DI water overnight prior to each adsorption experiment to ensure wetting of the pores.

Table 1. Properties of selected mercury sorbents

\begin{tabular}{|c|c|c|c|c|c|c|c|}
\hline $\begin{array}{c}\text { Sorbent } \\
\text { name }\end{array}$ & Manufacturer & $\begin{array}{c}\text { Nominal } \\
\text { particle } \\
\text { size } \\
(\mathrm{mm})\end{array}$ & Matrix & $\begin{array}{l}\text { Active } \\
\text { sites }\end{array}$ & $\begin{array}{c}\text { Recommended } \\
\text { flow rate } \\
\text { (BV/min) }\end{array}$ & $\begin{array}{c}\text { Reported } \\
\text { capacity } \\
(\mathbf{e q} / \mathrm{L})\end{array}$ & $\begin{array}{c}\text { Approx. } \\
\text { cost } \\
\left(\$ / \mathbf{f t}^{3}\right)\end{array}$ \\
\hline GT-74 & $\begin{array}{l}\text { Rohm and } \\
\text { Haas }\end{array}$ & $0.45-0.70$ & $\begin{array}{l}\text { Styrene-DVB } \\
\text { Macroporous }\end{array}$ & Thiol & $0.27-1.07$ & 1.3 & 1592 \\
\hline SIR-200 & ResinTech & $0.3-1.0$ & $\begin{array}{l}\text { Styrene-DVB } \\
\text { Macroporous }\end{array}$ & Thiol & $0.13-0.40$ & 1.2 & 375 \\
\hline $\begin{array}{l}\text { Dow } \\
43604\end{array}$ & Dow & $0.4-0.72$ & $\begin{array}{l}\text { Styrene-DVB } \\
\text { Macroporous }\end{array}$ & Thiol & & 0.7 & 529 \\
\hline Keyle:X & SolmeteX & $0.6-0.8$ & Polyacrylate & Thiol & $0.54-1.07$ & 3.4 & 1000 \\
\hline $\begin{array}{l}\text { Forager } \\
\text { M-TU }\end{array}$ & Dynaphore & 12.7 & Polymer & $\begin{array}{l}\text { Dithiocar- } \\
\text { bamate }\end{array}$ & $0.1-0.5$ & 0.1 & \\
\hline SAMMS & Steward & & Silica & Thiol & & 0.44 & $\begin{array}{l}900- \\
1600\end{array}$ \\
\hline KMS-1 & $\begin{array}{l}\text { Northwestern } \\
\text { University }\end{array}$ & 0.005 & $\mathrm{~K}_{2 x} \mathrm{Mn}_{x} \mathrm{Sn}_{3-x} \mathrm{~S}_{6}$ & Sulfide & N/A & $0.38 \mathrm{~g} / \mathrm{g}$ & N/A \\
\hline GAC & Calgon & $0.8-1.0$ & Carbon & $\begin{array}{c}\text { Activated } \\
\text { carbon }\end{array}$ & & 3.9 & 73 \\
\hline
\end{tabular}

\subsubsection{Sorption Kinetics}

Surrogate water used in these tests was made using tap water based on the analytical results in order to mimic storm drain water from the WEMA area. The starting mercury concentration was fixed at $40 \mathrm{ppb}$, which was the highest mercury concentration detected in WEMA storm drain water during a recent 2009 survey. A total of $0.14 \mathrm{~g}$ (dry weight) of resins, GAC, Forager Sponges, SAMMS, or KMS-1 [or $0.6 \mathrm{~g}$ (wet weight) of alginate-KMS-1] was weighed into $500 \mathrm{~mL}$ bottles. A $400 \mathrm{~mL}$ sample of the mercury solutions was added to each bottle. The bottles containing these slurries were shaken at room temperature $\left(22 \pm 1^{\circ} \mathrm{C}\right)$ for $8 \mathrm{~h}$. From each bottle, a $2 \mathrm{~mL}$ aliquot of the well-mixed slurry, was sampled at intervals of $5,10,30,60,180,360$, and $480 \mathrm{~min}$, and the aliquots were filtered immediately using an Acrodisc syringe filter (0.2 $\mu \mathrm{m}$ Supor ${ }^{\circledR}$ membrane). The filtrates were then preserved with $\mathrm{BrCl}(1 \%)$ and analyzed for total mercury concentration. Mercury was analyzed using a RA-915+ Mercury Spectrometer (Lumex, Twinsburg, Ohio) with a detection limit of 25 pg. A set of mercury solutions without the addition of sorbents was also treated in the same way to serve as controls.

\subsubsection{Sorption Isotherm}

Batch isotherm tests were carried out for selected sorbents in $40 \mathrm{~mL}$ amber glass vials with Teflonlined screw caps. The tests were initiated by adding known masses (0.01-0.02 g) of a sorbent to $30 \mathrm{~mL}$ of a surrogate aqueous solution containing an initial concentration of $0.04-100 \mathrm{mg} / \mathrm{L}$ as 
mercury. The mixture was then shaken on an orbital shaker for 4 days, which was sufficient to reach equilibrium as confirmed through separate kinetic tests. At equilibrium, water samples were taken from each vial and analyzed for mercury remaining in the solution. Mercury uptake was then calculated based on the mass balance equation

$$
q_{e}=\frac{V\left(C_{0}-C_{e}\right)}{M},
$$

where $q_{e}$ is the equilibrium mass uptake of mercury by a sorbent (mg/g), $V$ is the solution volume (L), $C_{0}$ and $C_{\mathrm{e}}$ are the initial and final concentration of mercury in solution, respectively (mg/L), and $M$ is the mass of a sorbent added $(\mathrm{g})$. All tests were carried out at room temperature $\left(22 \pm 1^{\circ} \mathrm{C}\right)$.

\subsubsection{Fixed-bed Column Tests}

Short-term column tests were performed to determine the relative performance of the selected sorbents from the batch tests and the minimum residence time to meet treatment requirements. The experimental setup included a Plexiglas column (11 $\mathrm{mm}$ in diameter and $15 \mathrm{~cm}$ in length), a peristaltic pump, and an Eldex automatic fraction collector. Approximately $5 \mathrm{~mL}$ of a resin was used

in each run. Surrogate water was introduced into the resin bed in a down-flow mode. After the column had been flushed for several bed volumes (BV), a sample was taken for mercury analysis. The pump speed was then adjusted and a new sample was collected after several bed volumes of surrogate solution had been pumped through the column. The maximum flow rate tested in this study was $5 \mathrm{BV} / \mathrm{min}$.

The long-term breakthrough behaviors of mercury will be evaluated in the same fixed-bed configuration. These tests will be performed to determine the mercury-loading characteristics for selected sorbents. A constant flow rate of $0.5 \mathrm{BV} / \mathrm{min}$ will be maintained, which translates to an empty bed contact time (EBCT) of $2.0 \mathrm{~min}$. The long-term column studies will end after pumping through 2000 BV of wastewater.

\subsubsection{Stability of Spent Sorbents}

TCLP tests were performed to quantify the mercury leachability of the spent sorbent following EPA Method 1311 (U.S. EPA, 1992) in order to determine the hazard classification of the spent sorbents for disposal purposes. TCLP fluid \#1 consists of $0.1 \mathrm{M}$ glacial acetic acid and $0.0643 \mathrm{M} \mathrm{NaOH}$, resulting in a solution of $\mathrm{pH} 4.93$. The extraction tests were carried out by mixing $5 \mathrm{ml}$ of spent sorbents from the column tests, which were washed three times with distilled water, with $45 \mathrm{~mL}$ TCLP fluid \#1 in a $60 \mathrm{ml}$ glass vial. The mixtures were rotated (30 rpm) for $18 \mathrm{~h}$ and centrifuged at 6000g (RCF) for $20 \mathrm{~min}$. The supernatant was then filtered through an Acrodisc syringe filter (0.2 $\mu \mathrm{m}$ Supor $^{\circledR}$ membrane). The filtrates were preserved with $\mathrm{BrCl}(1 \%)$ for mercury analysis.

\subsubsection{Preliminary Results}

\subsubsection{Sorption Kinetics}

Metal sorption process involves (1) transport of metal ions from the bulk solution to the sorbent particle and across the boundary layer to the surface sites, (2) pore diffusion, and (3) adsorption by 
physical or chemical interactions. In this study, high agitation rates removed the mass transfer resistance at the boundary layer. Therefore, the sorption kinetics is dependent on the pore diffusion considering that the $\mathrm{Hg}$ (II) adsorption reaction is instantaneous. Figure 4 shows the sorption kinetics of $\mathrm{Hg}$ (II) by six thiol- or sulfur-based resins (a) and six other sorbents (b). In general, thiol-based resin performed very well and was able to remove $40 \mu \mathrm{g} / \mathrm{L} \mathrm{Hg(II)} \mathrm{in} 8 \mathrm{~h}$. Almost all the sorbents, except chitosan, performed better than the base sorbent activated carbon, which is used at the Big Spring Wastewater Treatment System at the Y-12 NSC. The removal of Hg(II) by SAMMS (powder) and KMS-1 in the batch experiments was extremely fast (i.e., in minutes). This may be because SAMMS and KMS-1 are in microscale and pore diffusion is not as important as that in porous resin. After dispersion in calcium-alginate beads, the sorption rate of $\mathrm{Hg}$ (II) by KMS-1 became much slower as pore diffusion became the limiting factor. Note that the sorption of $\mathrm{Hg}(\mathrm{II})$ by alginateKMS-1 was still much faster than with thiol-based resins, and the $\mathrm{Hg}$ (II) was completely removed in less than an hour. The sorption kinetics of granular SAMMS is still under investigation due to lack of product availability until recently.

\subsubsection{Short-term Column Studies}

The results of the short-term column studies are summarized in Fig. 5. The fractional breakthrough for these studies was calculated as the ratio between outlet concentration and inlet concentration. Sorbents in powder forms (i.e., SAMMS, KMS-1, and chitosan) were not tested. Four sorbents, SIR-200, KeyleX, XUS, and GT-74, were found to have the best performance for removal of Hg(II) from the surrogate water. It is worth noting that granular activated carbon, the baseline technology, also performed very well at relatively low flow rate $(<1 \mathrm{BV} / \mathrm{min})$. For example, activated carbon can reduce $\mathrm{Hg}(\mathrm{II})$ to $\sim 100 \mathrm{ng} / \mathrm{L}$ at $0.5 \mathrm{BV} / \mathrm{min}$. M-TU and alginate-KMS-1 did not perform as well as other sorbents. This may be due to fractural or preferential flows in the sorbent bed due to the bulky nature of these two sorbents. We note that maximum water flow rates to achieve certain mercury removal would determine the size of the sorption reactor/bed. For example, to treat $100 \mathrm{gpm}$ wastewater, the BV would be 100 gal if the flow is $1 \mathrm{BV} / \mathrm{min}$. However, if the flow is $0.2 \mathrm{BV} / \mathrm{min}$, then the BV would increase to 500 gal.

TCLP tests were performed on the spent sorbents from the short-term sorption tests. The sorbed $\mathrm{Hg}$ (II) in the spent sorbents was very low $(<3.2 \mu \mathrm{g} \mathrm{Hg} / \mathrm{g}$ sorbent). Significant leaching was only observed from spent alginate-KMS-1. The reason for the mercury leaching from alginate-KMS-1 was not determined. The TCLP tests will be further performed on spent sorbents with higher mercury loading. The sorption isotherm tests and long-term column studies are still under investigation. The sorption capacity obtained from isotherm tests will determine the replacement frequency and annual costs. 


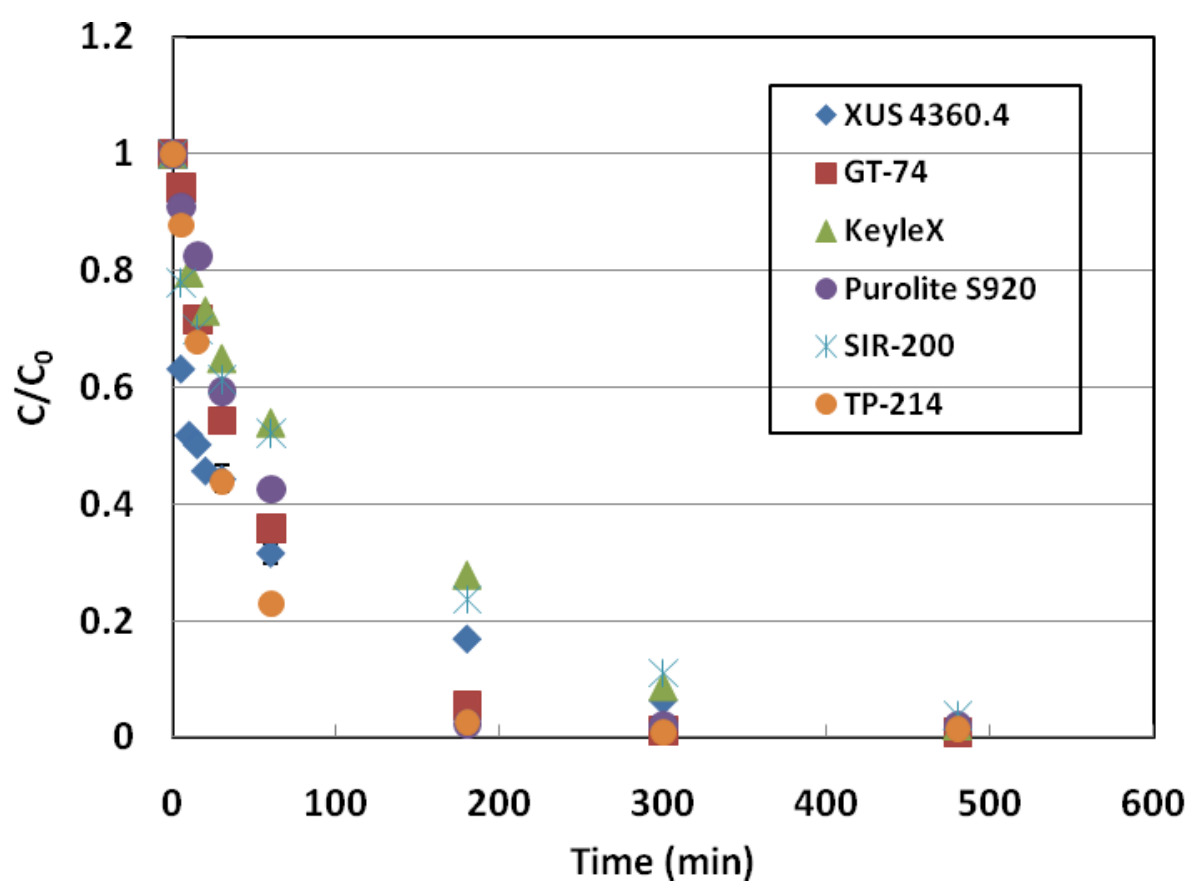

(a)

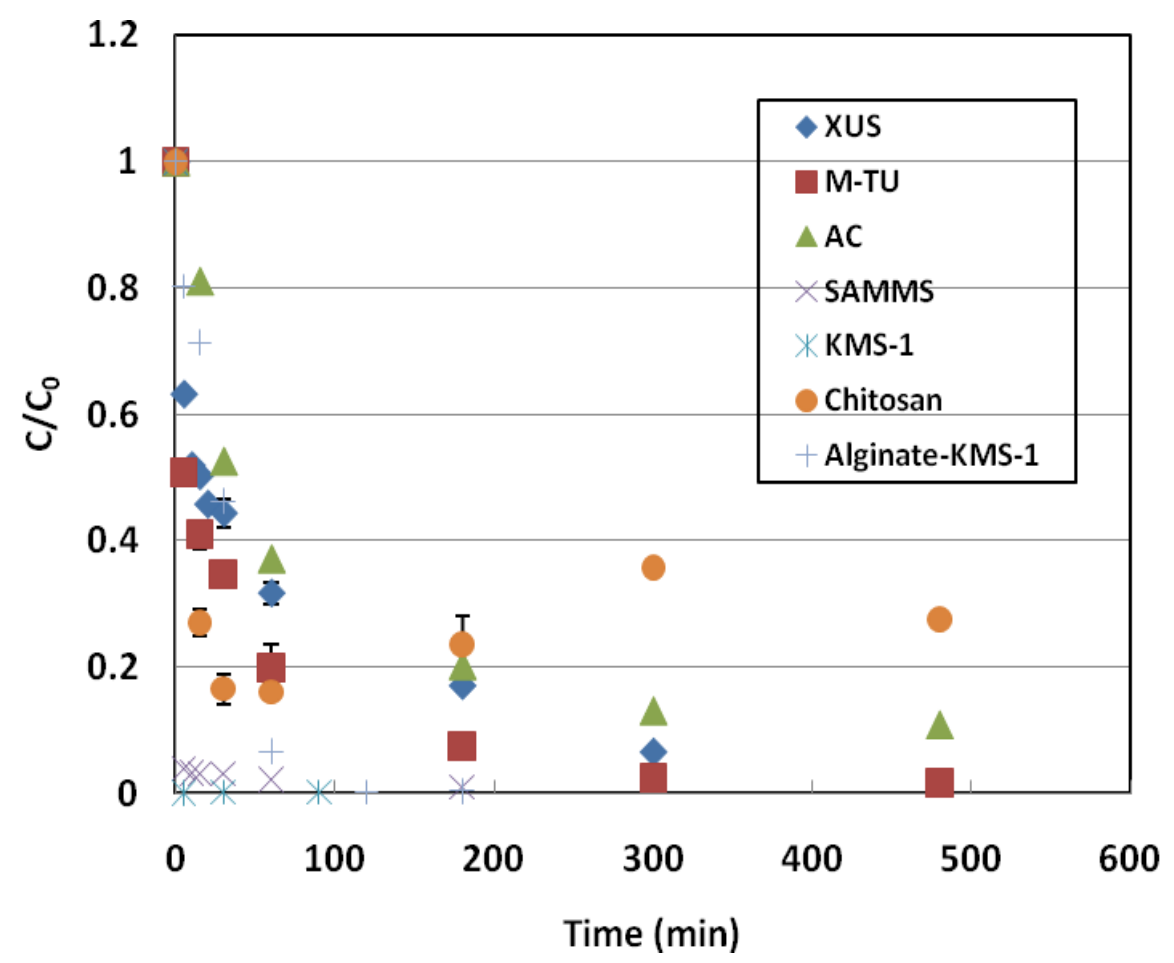

(b)

Fig. 4. Sorption kinetics of $\mathrm{Hg}$ (II) by thiol- or sulfur-based resins (a) and other sorbents (b). 


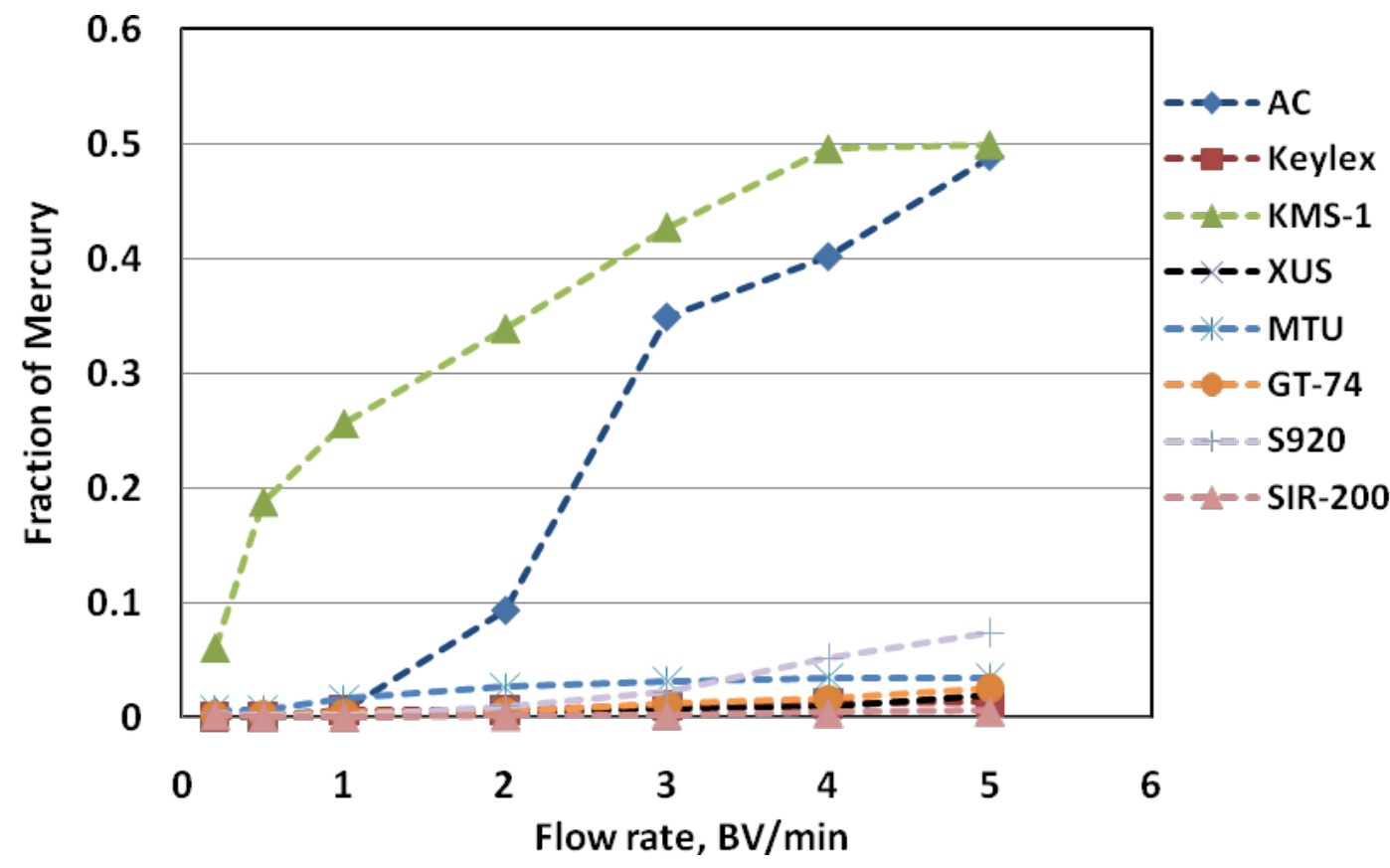

Fig. 5. Fraction of mercury breakthrough at outlet during short-term column studies (flow rate: 0.2 to $5 \mathrm{BV} / \mathrm{min})$.

\subsection{COST ANALYSIS}

The Big Spring Water Treatment System at Y-12 uses GAC-based technology. Capital costs for this 300 gpm treatment system were about \$1.7 million in 2002 (BJC, 2002). The treatment system includes six $8 \mathrm{ft}$ diameter by $8 \mathrm{ft}$ high carbon columns consisting of two parallel trains of three. A constant $150 \mathrm{gpm}$ flow is maintained for each flow train. Therefore, the flow rate through the GAC bed is about $0.05 \mathrm{BV} / \mathrm{min}$. With this low flow (and resulting long contact time) and two GAC reactors in series, the mercury concentration was able to be reduced from 2,500 ng/L in the influent to $130 \mathrm{ng} / \mathrm{L}$ in the effluent during pilot tests. To obtain mercury discharge levels below $51 \mathrm{ng} / \mathrm{L}$, an extra column was added to the two-column configuration in the full-scale operation. The O\&M costs for the system are approximately \$3.7 million. This cost was based on an annual operating cost of approximately $\$ 227,000$ escalated at a rate of $3.7 \%$ over 25 years. If a GAC system is used at Outfall 200 to treat 1300 gpm water, the engineering design itself is a challenge and the cost would be expected to be very high, much higher than the $\mathrm{SnCl}_{2} /$ air stripping process.

Interestingly, an oxidation-reduction process was also evaluated during the technology evaluation of this treatment system (BJC, 2002). The oxidation-reduction process used UV/ozone as an oxidant to oxidize all the mercury to $\mathrm{Hg}$ (II) form and then used $\mathrm{SnCl}_{2}$ as a reductant to reduce the $\mathrm{Hg}$ (II) to gaseous mercury followed by air stripping. The estimated capital costs for this system was \$1.5 million and O\&M costs were about $\$ 4.0$ million. The O\&M cost was based on an annual operating cost of approximately $\$ 249,000$ escalated at a rate of 3.7\% over 25 years. Therefore, the cost of this system was very similar to that of the GAC system. During the pilot test, the oxidation-reduction 
method was not able to achieve the $51 \mathrm{ng} / \mathrm{L}$ goal. The effluent concentration ranged from 67 to 148 ng/L during five sampling events.

We note that the study of sorption in this report is primarily targeted at the mercury removal in source areas, where this technology becomes attractive. However, the results from this study can also be used to evaluate possible options for mercury removal at Outfall 200 or Station 17. In this section, we demonstrated that several thiol-based resins have the potential to process the Y-12 water at relatively high flow rates and require much smaller reactors. Since the thiol-based resins are typically more expensive, the smaller reactors help offset the higher cost of the sorbent. Klasson et al. (2000) reported a functional relationship between the construction cost and processing flow rate. This relationship is shown in Fig. 6. In the figure, the base case was a GAC system treating water at $1 \mathrm{~m}^{3} / \mathrm{min}$ with a processing rate of $0.1 \mathrm{BV} / \mathrm{min}$. The construction cost for such a system, including an initial charge of carbon, was about $\$ 197,000$. From Fig. 6 , a system with a sorbent cost of $\$ 1000 / \mathrm{ft}^{3}$ would have to operate at a processing flow rate of $0.67 \mathrm{BV} / \mathrm{min}$ or higher to cost the same as the GAC system. Based on our results, SIR-200, XUS, GT-74, and Keyle:X have the potential to meet the requirement. The annual cost of replacement of the sorbent is directly proportional to the cost of the sorbent and the replacement frequency. The replacement frequency depends on the sorptive capacity. A sorbent costing $\$ 1000 / \mathrm{ft}^{3}$ would have to have a sorption capacity of about 30 times that of carbon at $\$ 32 / \mathrm{ft}^{3}$ (in Fig. 6) to have the same annual cost (GAC currently at $\$ 73 / \mathrm{ft}^{3}$ ). The sorptive capacity depends on the water chemistry and mercury concentration and may deviate significantly from the reported capacity given in Table 1 . In addition, the costs of secondary waste disposal are significant. Pacific Northwest National Laboratory (2010) estimated the waste disposal cost was $\sim \$ 60 / \mathrm{ft}^{3}$. Therefore, if a sorbent has a mercury capacity of 30 times of that of GAC, the waste disposal cost will be only $1 / 30$ of that of GAC. Pacific Northwest National Laboratory further estimated that the total cost per kilogram of mercury removed is $\$ 2,010$ for SAMMS, compared to \$6,960 for GT-73 and $\$ 261,000$ for GAC using mixed cost data from various sources. We caution that these costs may not hold true when the three sorbents are used for treating water at Y-12.

From the analysis above and in Section 3, we show that a full-scale sorption treatment system at Outfall 200 may cost more than a $\mathrm{SnCl}_{2}$ /air stripping system. However, the costs can be significantly reduced if the treatment system is implemented at the source areas. The sorption technology has proven treatment efficiency, reliability, and no environmental uncertainties in full-scale application. However, whether or not $\mathrm{SnCl}_{2}$ /air stripping process can achieve significant mercury removal at Outfall 200 is yet to be proved in the pilot-scale test. A cost estimation for O\&M cost of $\mathrm{SnCl}_{2}$ /air stripping system can also be reevaluated during the pilot test. One advantage of the $\mathrm{SnCl}_{2} /$ air stripping system is that it does not generate much secondary waste, which is not the case for the sorption process. In addition, whether or not thiol-based resins such as SIR-200, XUS, GT-74, and Keyle:X and SAMMS can replace GAC as the sorbent will depend on the sorptive capacity of these sorbents at field conditions (lab testing ongoing). Another option is that GAC can be used as a primary sorbent followed by a polishing sorbent such as SIR-200. This may cut the total cost and will be further tested in our lab studies. 


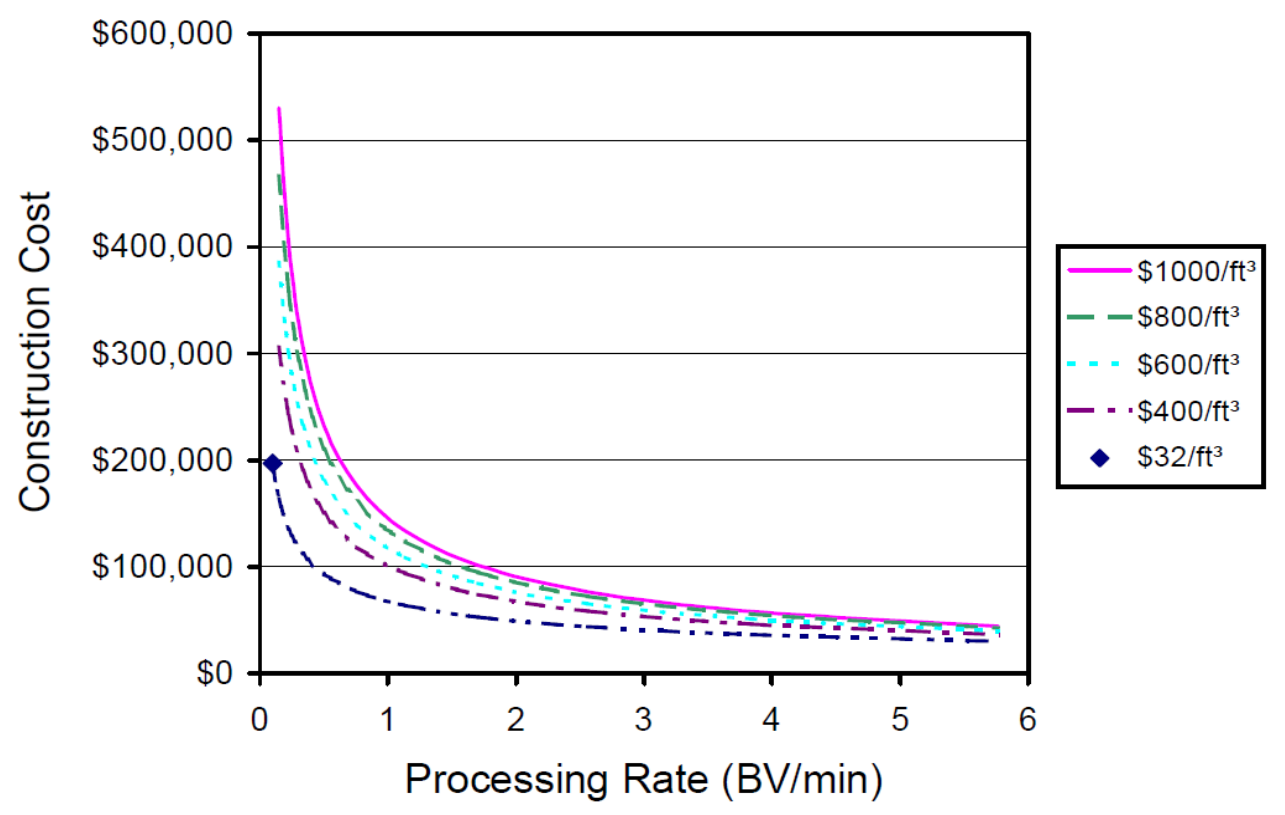

Fig. 6. Construction cost as a function of processing flow rate and sorbent cost (from Klasson et al., 2000).

We have pointed out that most of the baseflow mercury at Outfall 200 arises from a small number of short sections of storm drain at WEMA and the total flow of these sections is about $213 \mathrm{~m}^{3} / \mathrm{d}$. The Y-12 April 2010 sampling results showed that the mercury flux from the WEMA comprised $~ 98 \%$ of mercury flux at Outfall 200 (Peterson et al., 2010), which comprised of $\sim 78 \%$ of mercury flux at Station 17. Therefore, $90 \%$ removal of mercury at the source area will reduce $\sim 90 \%$ of the mercury flux at Outfall 200 and $\sim 70 \%$ at Station 17. The capital cost of a sorption system to treat $213 \mathrm{~m}^{3} / \mathrm{d}$ water is expected to be less than $\$ 500,000$, and the O\&M costs will be less than $\$ 100,000 /$ year. The disadvantage of this option is that it is sensitive to the decontamination and decommissioning (D\&D) and storm drain sediment cleanup activity. These remedial activities could significantly change the distribution of mercury in the storm drain system. However, a compact mobile sorption system can be built to adapt that change and meet the emergency treatment requirement. Another disadvantage of moving the treatment to the high source outfalls is that these are within the secure area of Y-12. This will likely increase the cost of implementation and maintenance. 


\section{CONCLUSIONS AND RECOMMENDATIONS}

This report evaluates the commercially available options for waterborne mercury treatment and analyzes the results of lab and field studies performed at ORNL for the selection of a mercury removal technology at Y-12 NSC. A summary of the factors considered for $\mathrm{SnCl}_{2} /$ air stripping and adsorption processes is provided in Table 2. The GAC system is used as an example of the adsorption process. A thiol-based sorbent or a combination of GAC with a thiol-based sorbent (polishing sorbent) may be more efficient and cost-effective, depending on the treatment goal.

Table 2. Technology comparison between adsorption and $\mathrm{SnCl}_{2} /$ air stripping

\begin{tabular}{|c|c|c|}
\hline Factors & GAC & SnCl $_{2}$ /Air stripping \\
\hline $\begin{array}{l}\text { Treatment goal } \\
\text { (e.g., } 51 \mathrm{ng} / \mathrm{L} \text { ) }\end{array}$ & $\begin{array}{l}\text { Achievable at Y-12 given enough } \\
\text { residence time }\end{array}$ & - $\quad$ Not demonstrated in the pilot scale \\
\hline Technology Maturity & $\begin{array}{l}\text { - Standard wastewater treatment } \\
\text { technology } \\
\text { - } \quad \text { Proven for mercury treatment at Y- } \\
12 \text { NSC }\end{array}$ & $\begin{array}{ll}\text { - } & \text { Standard wastewater treatment } \\
\text { equipment } & \\
\text { - } & \text { Proven for mercury removal at SRS } \\
\text { - } & \text { Not field tested at Y-12 }\end{array}$ \\
\hline Treatment Equipment & - $\quad$ GAC bed with pumps & $\begin{array}{ll}\text { - Air stripper with pumps and air } \\
\text { compressor }\end{array}$ \\
\hline Support Equipment & - $\quad$ Pre-filtration bed & $\begin{array}{ll}- & \text { Pre-filtration bed } \\
- & \text { Dechlorination system } \\
\text { - } & \text { Metering pump for adding } \mathrm{SnCl}_{2} \\
\end{array}$ \\
\hline Secondary Waste & $\begin{array}{ll}\text { - } & \text { Spent GAC and backwash water } \\
\text { - } & \text { Spent filter }\end{array}$ & $\begin{array}{l}\text { - Spent filter, if } \mathrm{Sn} \text { is an issue, sorption } \\
\text { may be needed to collect tin } \\
\text { by-products }\end{array}$ \\
\hline Chlorine Effect & - $\quad$ Diminish the sorbent capacity & $\begin{array}{ll}\text { - Diminish the reducing capacity of } \\
\mathrm{SnCl}_{2}\end{array}$ \\
\hline Uncertainties & - $\quad$ None & $\begin{array}{l}\text { - Fate of tin, tin methylation, and its } \\
\text { mediated mercury methylation }\end{array}$ \\
\hline $\operatorname{Cost}^{a}$ & $\begin{array}{l}\text { - Capital: \$2.0 million (300 gpm } \\
\text { GAC system) } \\
\text { - O\&M: \$0.27million/year (300 gpm } \\
\text { GAC system) } \\
\end{array}$ & $\begin{array}{ll}\text { - } & \text { Capital: } \$ 2.2 \text { million } \\
\text { - } & \text { O\&M: } \$ 1.0 \text { million/year }\end{array}$ \\
\hline
\end{tabular}

${ }^{a}$ The flow at Outfall 200 is $~ 1300$ gpm. The cost of GAC system will vary significantly depending on the treatment goal and the figuration (e.g., combining with thiol-based sorbents). The cost of secondary waste disposal is not included.

\subsection{CONCLUSIONS}

The following conclusions can be made.

- Both adsorption (e.g., GAC system) and $\mathrm{SnCl}_{2}$ /air stripping have the capability to remove mercury from Outfall 200 or from the storm drainage in the WEMA source areas.

- The sorption system has proven performance in full scale at Y-12 NSC to achieve high mercury removal efficiency. The performance of $\mathrm{SnCl}_{2} /$ air stripping system needs to be demonstrated at pilot scale. 
- The sorption system is a standard wastewater treatment technology without uncertainties associated with it; however, the $\mathrm{SnCl}_{2}$ /air stripping process has uncertainties associated with tin accumulation, tin methylation, and its possible mediated abiotic mercury methylation in EFPC.

- Treating Hg-contaminated water at source areas will reduce the treated water from $7100 \mathrm{~m}^{3} / \mathrm{d}$ to $213 \mathrm{~m}^{3} / \mathrm{d}$, which would significantly reduce the treatment costs as well as the waste disposal costs. Based on the site conceptual model (Peterson et al., 2010), a 90\% removal of mercury at the source area will reduce $\sim 90 \%$ of the mercury flux at Outfall 200 and $\sim 70 \%$ at Station 17.

\subsection{RECOMMENDATIONS}

Based on the information currently available and the results of our analysis, we have several technical recommendations. Any of these recommendations will need to be processed through site compliance and regulatory approval. Some of the recommendations have been taken up by the DOE- Oak Ridge Operations as ongoing activities.

- A pilot-scale test is being planned for $\mathrm{SnCl}_{2}$ /air stripping process at Outfall 200 to evaluate its performance at field scale.

- An environmental risk and impact study on the introduction of tin into the EFPC ecosystem.

- Continuation of sorbent capacity studies and long-term column studies using field water from the Y-12 WEMA storm drain.

- Performance of a pilot-scale test to get full-scale design parameters if an in situ sorption trial proves promising in terms of operational cost. 


\section{REFERENCES}

Bailey, S., Olin, T. J., Bricka, R. M., Dean Adrian, D., 1999. “A review of potentially low-cost sorbents for heavy metals,” Water Res. 33, 2469-2479.

Bard, A. J., Parsons, R., Jordan, J., 1985. Standard potentials in aqueous solution. Marcel Dekker, Inc., New York.

Benhammou, A., Yaacoubi, A., Nibou, L., Tanouti, B., 2005. “Adsorption of metal ions onto Moroccan stevensite: Kinetic and isotherm studies,” J. Colloid Interface Sci. 282, 320-326.

BJC (Bechtel Jacobs Co. LLC), 2002. Technology Evaluation for the Big Spring Water treatment System at the Y-12 National Security Complex, Oak Ridge, Tennessee. BJC/OR-1239. Prepared by Tetra Tech, Inc.

Blanchard, G., Maunaye, M., Martin, G., 1984. "Removal of heavy-metals from waters by means of natural zeolites,” Water Res. 18, 1501-1507.

Borsook, H., Keighley, G., 1933. "Oxidation-Reduction Potential of Ascorbic Acid (Vitamin C)," Proc. Natl. Acad. Sci. USA. 19, 875-878.

Celo, V., Lean, D. R. S., Scott, S. L., 2006. "Abiotic methylation of mercury in the aquatic environment,” Science of the Total Environment 368, 126-37.

Chang, Y. H., Huang, C. F., Hsu, W. J., Chang, F. C., 2007. "Removal of $\mathrm{Hg}^{2+}$ from aqueous solution using alginate gel containing chitosan,” J. Appl. Polym. Sci. 104, 2896-2905.

Chen, X., Feng, X., Liu, J., Fryxell, G. E., Gong, M. L., 1999. "Mercury separation and immobilization using self-assembled monolayers on mesoporous supports (SAMMS)," Sep. Sci. Technol. 34, $1121-1132$.

Chiarle, S., Ratto, M., Rovatti, M., 2000. "Mercury removal from water by ion exchange resins adsorption,” Water Res. 34, 2971-2978.

Feng, X., Fryxell, G. E., Wang, L. Q., Kim, A. Y., Liu, J., 1997. “Organic monolayers on ordered mesoporous supports," Science 276, 923-926.

Fondeur, F. F., Van Pelt, W. B., Fink, S. D., 2002. Mercury Removal Performance of Amberlit ${ }^{T M} G T$ 73A, Purolite ${ }^{T M}$ S-920, Ionac ${ }^{T M}$ SR-4 and SIR-200 ${ }^{T M}$ Resins. WSRC-TR-2002-00046, Westinghouse Savannah River Company, Aiken SC 29808.

Gilmour, C. C., Tuttle, J. H., Means, J. C., 1987. “Anaerobic Microbial Methylation of Inorganic Tin in Estuarine Sediment Slurries,” Microb Ecol. 14, 233-242.

Hamasaki, T., Nagase, H., Yoshioka, Y., Sato, T. 1995. "Formation, distribution, and ecotoxicology of methylmetals of tin, merccury, and arsenic in the environment," Critical Reviews in Environmental Science and Technology 25, 45-91.

Herrero, R., Lodeiro, P., Rey-Castro, C., Vilarino, T., Sastre de Vicente, M., 2005. "Removal of inorganic mercury from aqueous solutions by biomass of the marine macroalga Cystoseira baccata,” Water Res. 39, 3199-3210.

Hollerman, W., Holland, L., Ila, D., Hensely, J., Southworth, G., Klasson, T., Taylor, P., Johnston, J., Turner, R., 1999. "Results from the low level mercury sorbent test at the Oak Ridge Y-12 plant in Tennessee,” J. Hazard. Mater. B68, 193-203.

Klasson, K. T., Bostick, D. T., Farr, L. L., McTaggart, D. R., Taylor, P. A., 2000. Demonstration of Mercury Sorbents to Meet DOE Customer Needs, ORNL/TM-2000/12. Oak Ridge National Laboratory, Oak Ridge, Tennessee. 
Lagadic, I. L., Mitchell, M. K., Payne, B. D., 2001. "Highly effective adsorption of heavy metal ions by a thiol-functionalized magnesium phyllosilicate clay,” Environ. Sci. Technol. 35, 984-990.

Lloyd-Jones, P. J., Rangel-Mendez, J. R., Streat, M., 2004. “Mercury sorption from aqueous solution by chelating ion exchange resins, activated carbon, and a biosorbent," Trans. IChemE. Pt. B 82, 301-311.

Looney, B. B., Denham, M. E., Vangelas, K. M., Koch, J. W., 2000. Ultralow Level Mercury Treatment Using Chemical Reduction and Air Stripping, WSRC-RP-2000-00028, Westinghouse Savannah River Company, Aiken, SC 29808.

Jackson, D. G., Looney, B. B., 2009. "Removal of mercury in groundwater via chemical reduction and air stripping,” DOE Mercury Summit, Nashville, Tennessee.

Manos, M. J., Kanatzidis, M. G., 2009. "Sequestration of heavy metals from water with layered metal sulfides,” Chem. Eur. J. 15, 4779-4784.

Mattigod, S., Fryxell, G., Skaggs, R., 2009. "SAMMS ${ }^{\circledR}$ technology for effective removal of mercury,” DOE Mercury Summit, Nashville, Tennessee.

Merrifield, J. D., Davids, W. G., Macrae, J. D., Amirbahman, A., 2004. "Uptake of mercury by thiolgrafted chitosan gel beads,” Water Res. 38, 3132-3138.

Miller, C. L., Southworth, G., Brooks, S., Liang, L. Y., Gu, B. H., 2009. "Kinetics controls on the complexation between mercury and dissolved organic matter in a contaminated environment," Environ. Sci. Tech. 43, 8548-8553.

Miretzky, P., Fernandez Cirelli, A., 2009. "Hg(II) removal from water by chitosan and chitosan derivatives: A review,” J. Hazard. Mater. 167, 10-23.

Monson, P. R., Bell, N. C., Serkiz, S. M., 2000. Evaluation of Selective Ion Exchange Resins for Removal of Mercury from the H-Area Water Treatment Unit, WSRC-TR-2000-00109, Westinghouse Savannah River Company, Aiken SC 29808.

MSE Technology Application, Inc., 2008. "Removal of Mercury (II) from Oak Ridge National Laboratory (ORNL) Surrogate Sump Water Using Chelating Resins.” Internal communication.

Nam, K. H., Tavlarides, L. L., 2003. "Mercury removal from acidic waste solutions using a thiol functional organo-ceramic adsorbent solvent,” Extr. Ion Exch. 21, 899-913.

Natale, F., Lancia, A., Molino, A., Natale, M., Karatza, D., Musmarra, D., 2006. "Capture of mercury ions by natural and industrial materials,” J. Hazard. Mater. 132, 220-225.

Pacific Northwest National Laboratory (PNNL), SAMMS technical summary. http://samms.pnl.gov/samms.pdf. Accessed in 11/2010.

Peterson, M., Looney, B., Southworth, G., Eddy-Dilek, C., Watson, D., Bogle, M. A., Ketelle, R., 2010. Conceptual model for primary mercury sources, transport pathways, and flux at the Y-12 complex and upper East Fork Poplar Creek, Oak Ridge, Tennessee. In preparation.

Ritter, J. A., Bibler, J. P., 1992. "Removal of mercury from waste water: Large-scale performance of an ion exchange process,” Water Sci. Technol. 25, 165-172.

Rorrer, G. L., Hsien, T. Y., Way, J. D., 1993. "Magnetic chitosan beads for removal of cadmium ions from waste water," Ind. Eng. Chem. Res. 32, 2170-2178.

Shafaei, A., Ashtiani, F. Z., Kaghazchi, T., 2007. "Equilibrium studies of the sorption of Hg(II) ions onto chitosan,” Chem. Eng. J. 133, 311-316.

Southworth, G., 1996. “Outfall 51 Treatment System”, pp. 2-2 and 2-3 in Mercury Abatement Report on the U. S. Department of Energy's Oak Ridge Y-12 Plant for the Fiscal Year 1996, Y/ER-277, Oak Ridge Y-12 Plant, Oak Ridge, Tennessee. 
Southworth, G. 1997. Proposed Experiment for $\mathrm{SnCl}_{2}$ Treatment of Outfall 200 for the Purpose of Mercury Removal from East Fork Poplar Creek, Y-12 Plant, Oak Ridge, Tennessee, 7 pp, Y/TS-1663, Martin Marietta Energy Systems Y-12 Plant, Oak Ridge, Tennessee.

Southworth, G. R., Brooks, S., Peterson, M., Bogle, M. A., Miller, C., Elliot, M., Liang, L., 2009. Controlling Mercury Release from Source Zones to Surface Water: Initial Results of Pilot Tests at the Y-12 National Security Complex, ORNL/TM-2009/035, Oak Ridge National Laboratory, Oak Ridge, Tennessee.

Southworth, G. R., Bogle, M. A., Brooks, S., Liang, L., Peterson, M., Spalding, B., Watson, D., Zhang, F., Abraham, T. J., 2010. Evaluation of New Options for Reducing Mercury Release at the Y-12 National Security Complex, ORNL/TM-2009. Oak Ridge National Laboratory, Oak Ridge, Tennessee.

Tharin, D. W., 1974. "Tire rubber removes mercury from process stream,” presented at the Fourth Annual Environmental Engineering and Science Conference in Louisville, Kentucky.

Tonini, D. R., Gauvin, D. A., Soffel, R. W., Freeman, W. P., 2004. “Achieving low mercury concentrations in chlor-alkali wastewaters,” Environ. Prog. 22, 167-173.

U.S. Environmental Protection Agency (EPA), 1992. EPA Test Method 1311 - TCLP, Toxicity Characteristic Leaching Procedure.

U.S. Environmental Protection Agency (EPA), Office of Research and Development, 1997. Aqueous Mercury Treatment, EPA/625/R-97/004, July.

U.S. Environmental Protection Agency (EPA), Office of Solid Waste and Emergency Response, 2007. Treatment Technologies for Mercury in Soil, Waste, and Water, EPA-542-R-07-003, August.

Varma, A. J., Deshpande, S. V., Kennedy, J. F., 2004. "Metal complexation by chitosan and its derivatives: a review,” Carbohydr. Polym. 55, 77-93.

Wagner-Dobler, I., von Canstien, H., Li, Y., Timmis, K. N., Deckwer, W. D. 2000. "Removal of mercury from chemical wastewater by microorganisms in technical scale,” Environ. Sci. Technol. 34, 4628-4634.

Walcarius, A., Delacote, C., 2005. "Mercury(II) binding to thiol-functionalized mesoporous silicas: critical effect of $\mathrm{pH}$ and sorbent properties on capacity and selectivity,” Anal. Chim. Acta 547, 3-13. 